\title{
Hetven év emlékei fényképeken
}

Összeállította: Szentpéteri József és Varga Máté

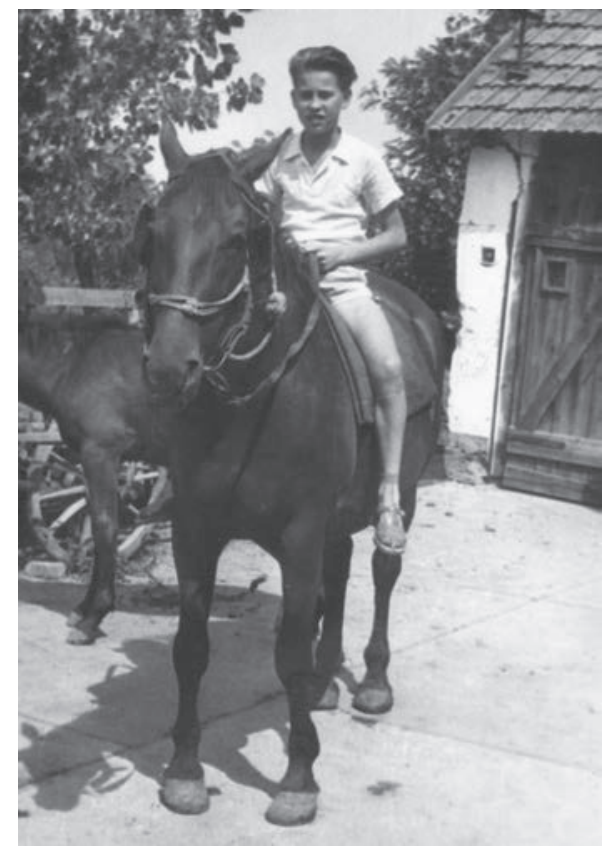

Költő László, 1958

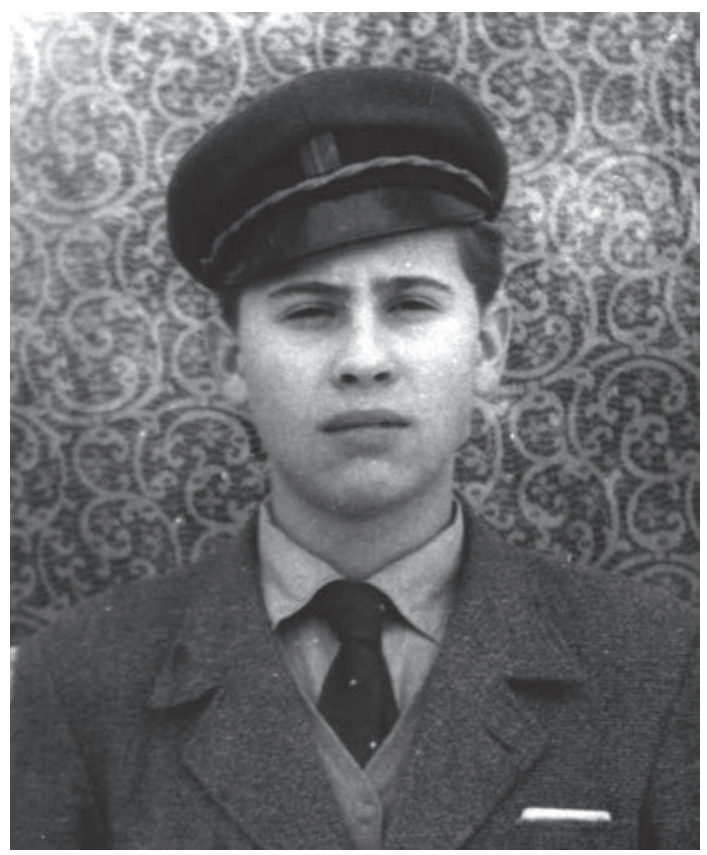

Vegyipari Technikum, Debrecen, 1963-1967

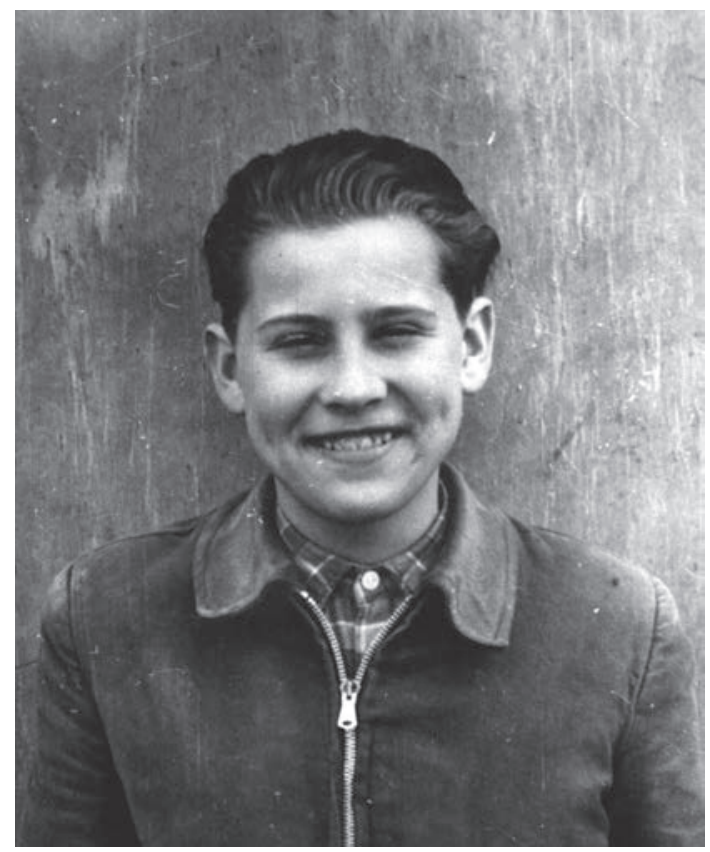

Költő László, 1960

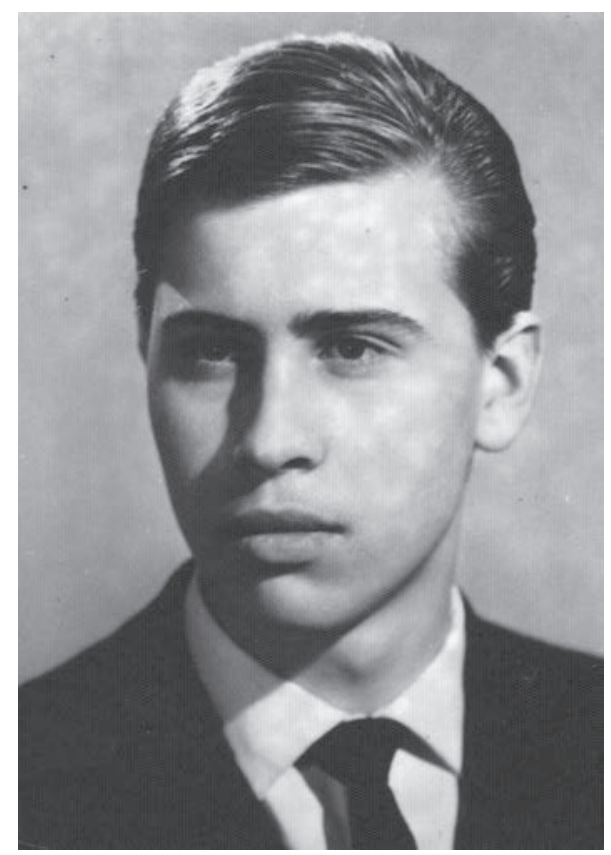

Érettségi tablókép, 1967 


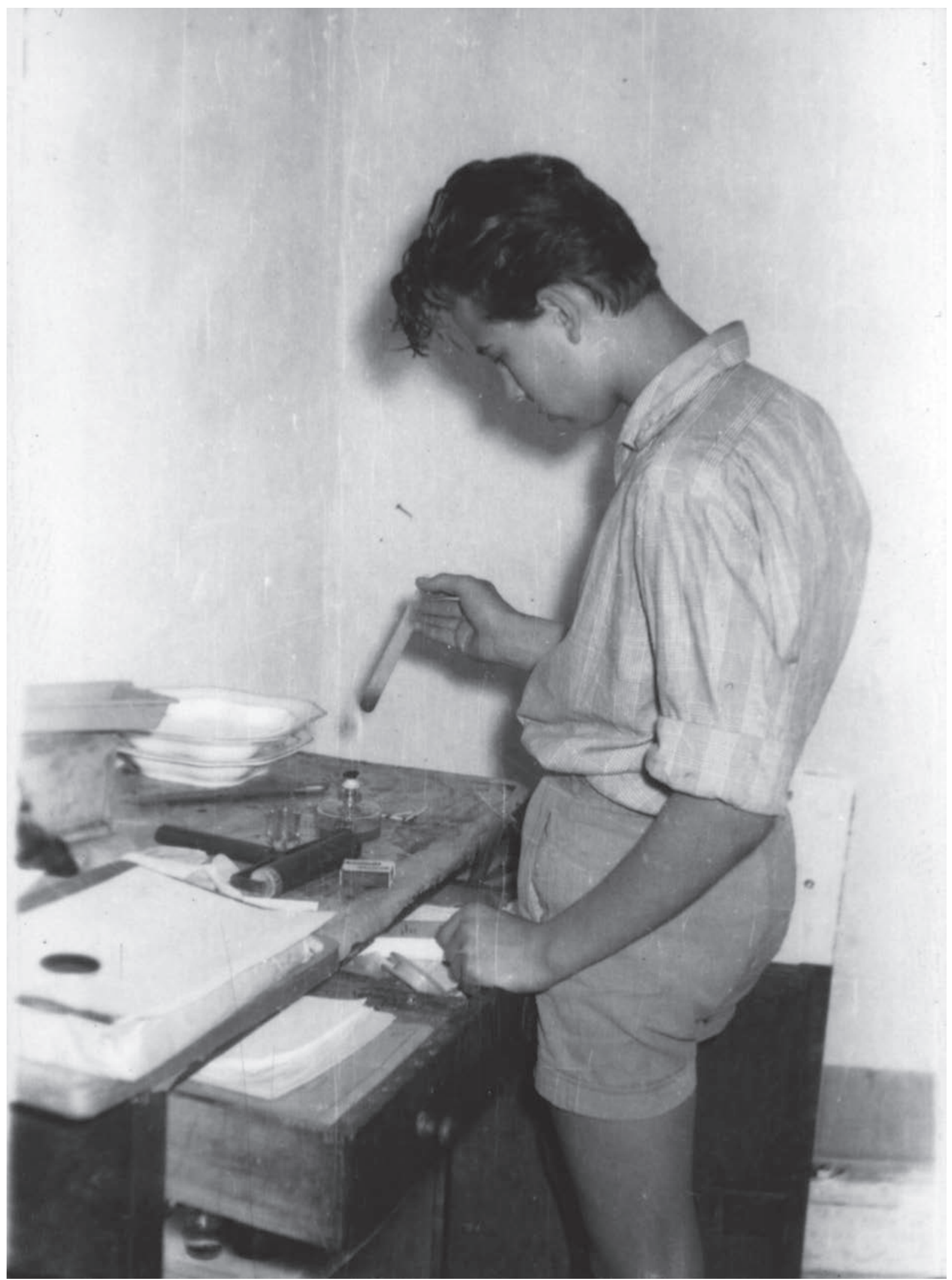

Költő László, 1962 


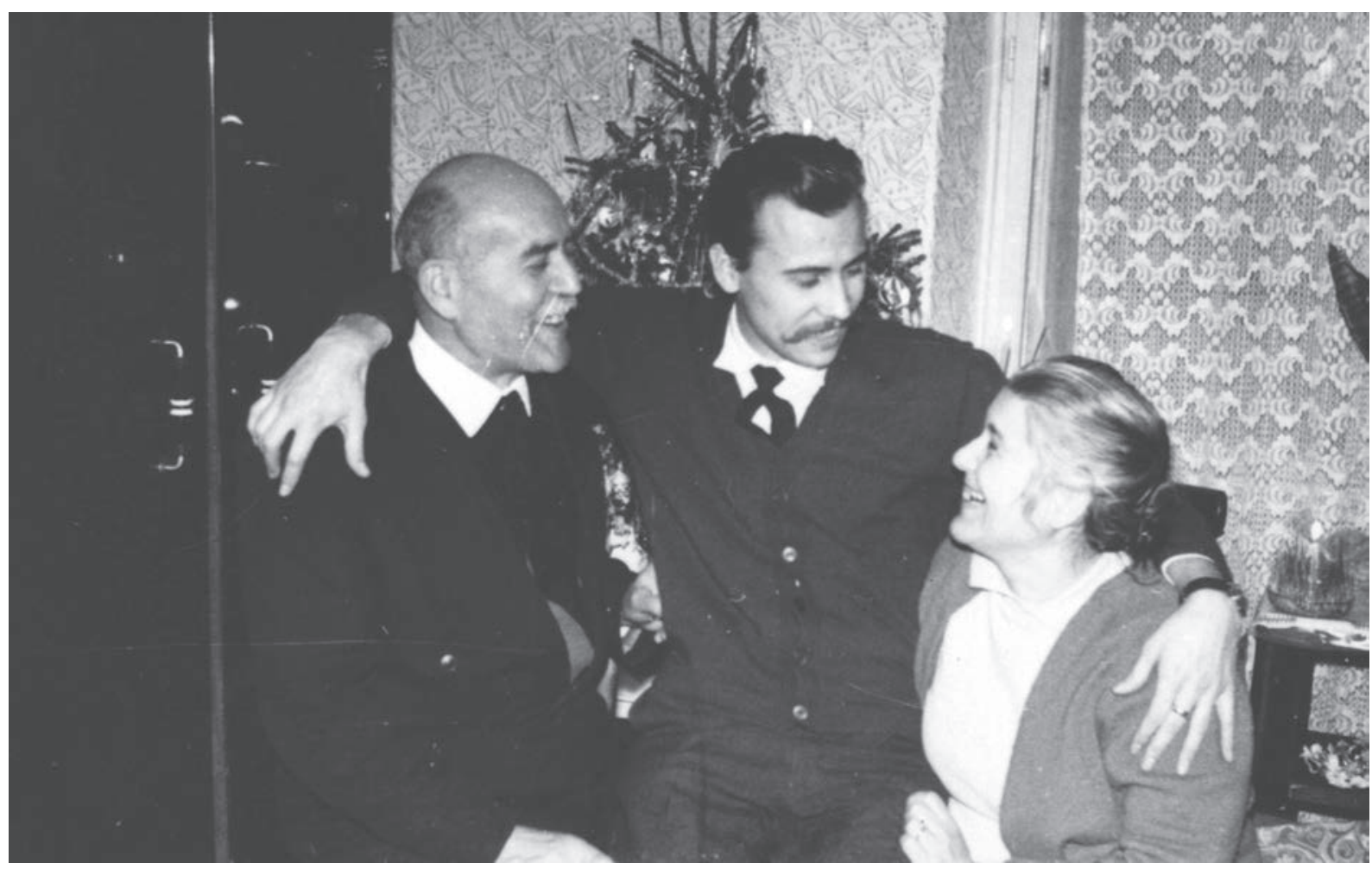

Költő László a szüleivel

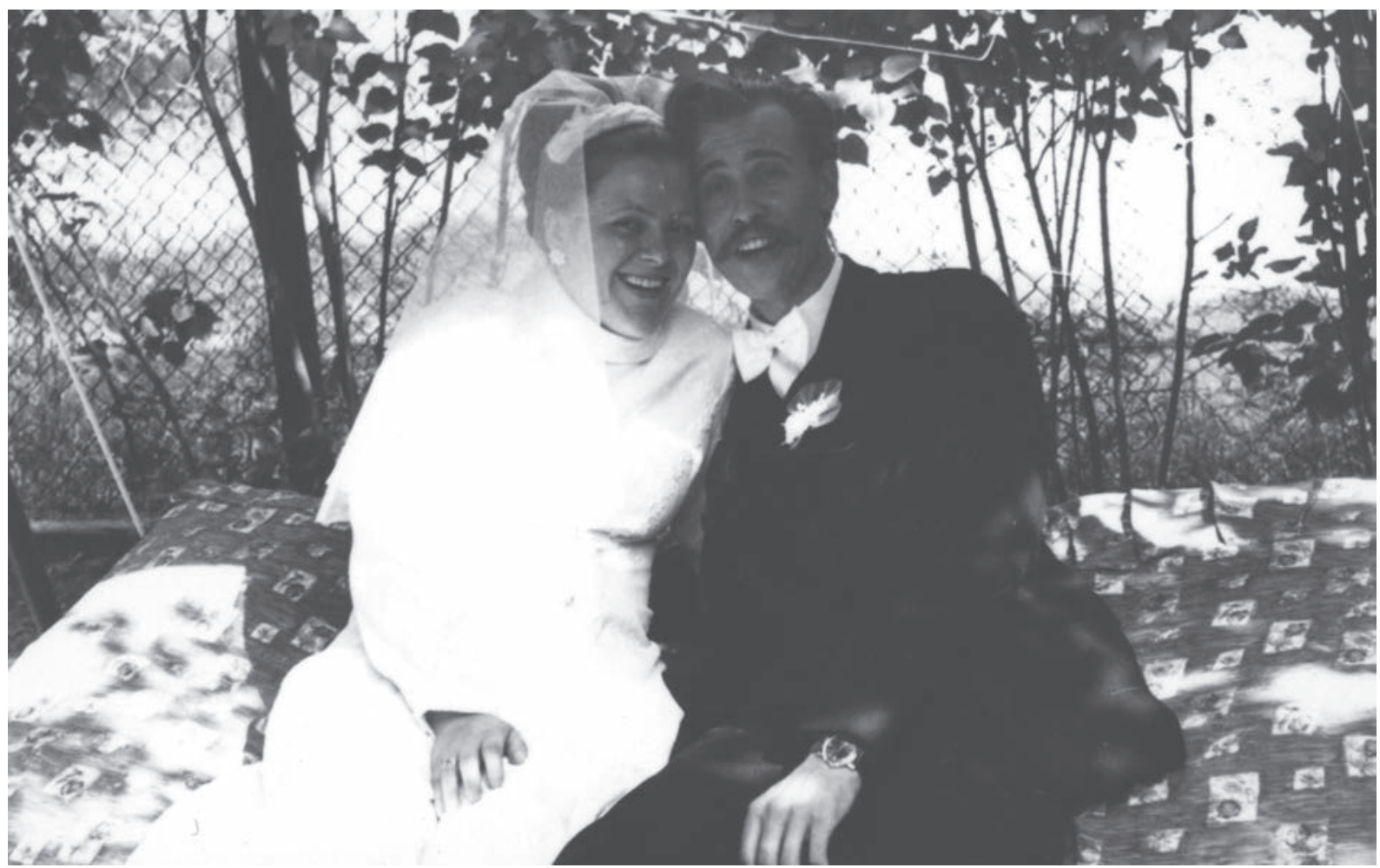

Both Zsuzsanna és Költő László esküvője, 1973 


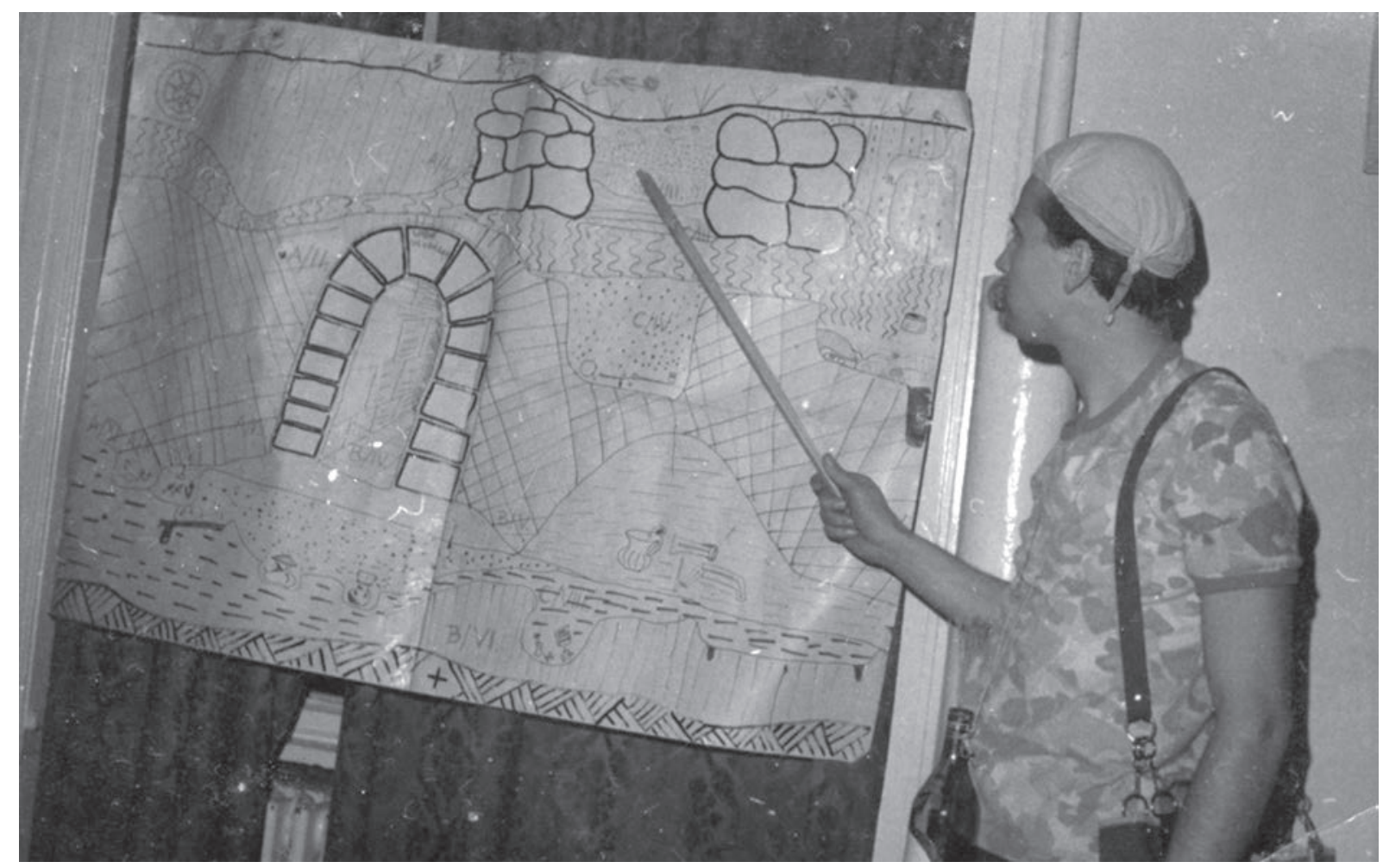

Tanszéki est, 1976

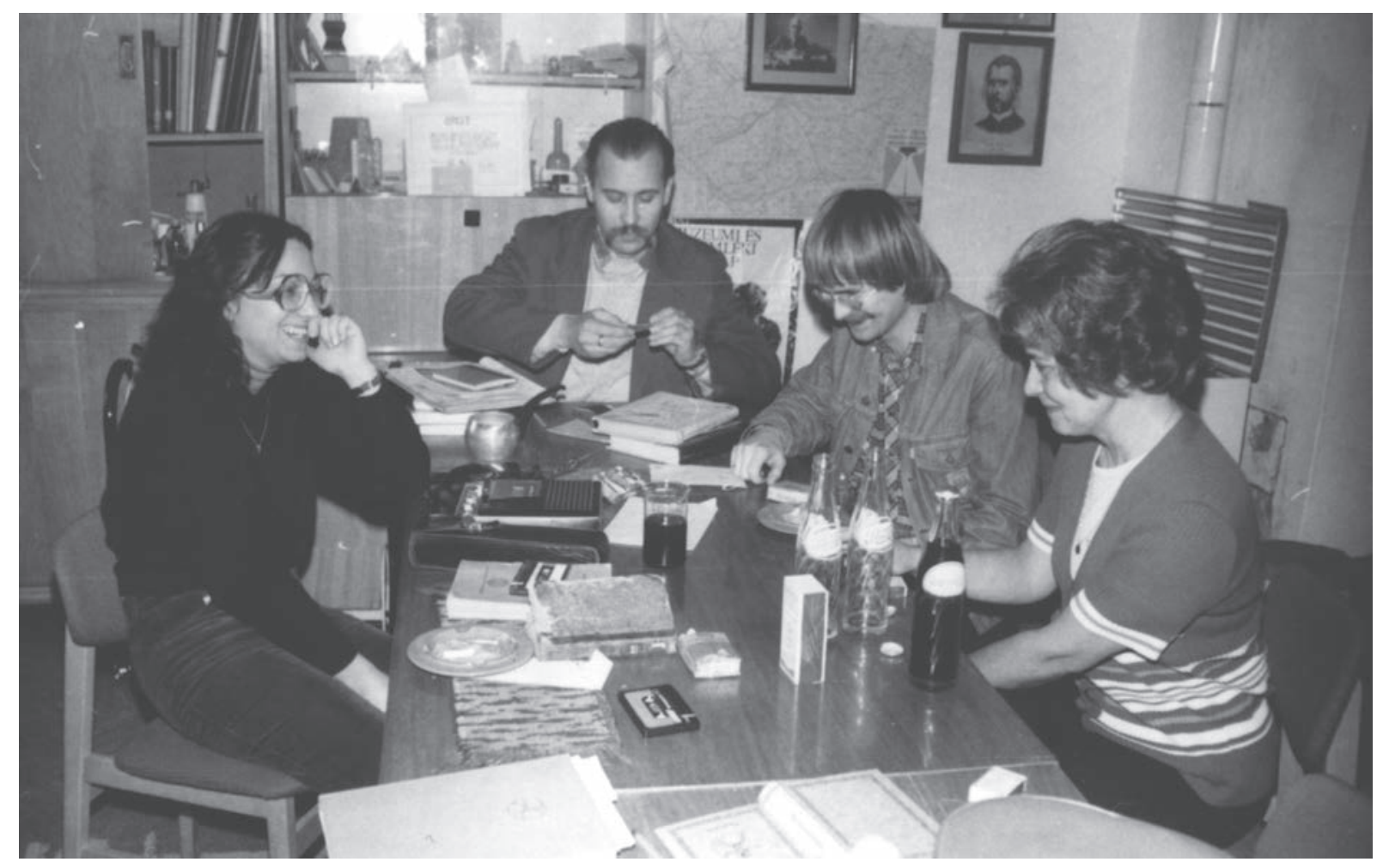

Várpalotai Vegyipari Múzeum, 1970-es évek 


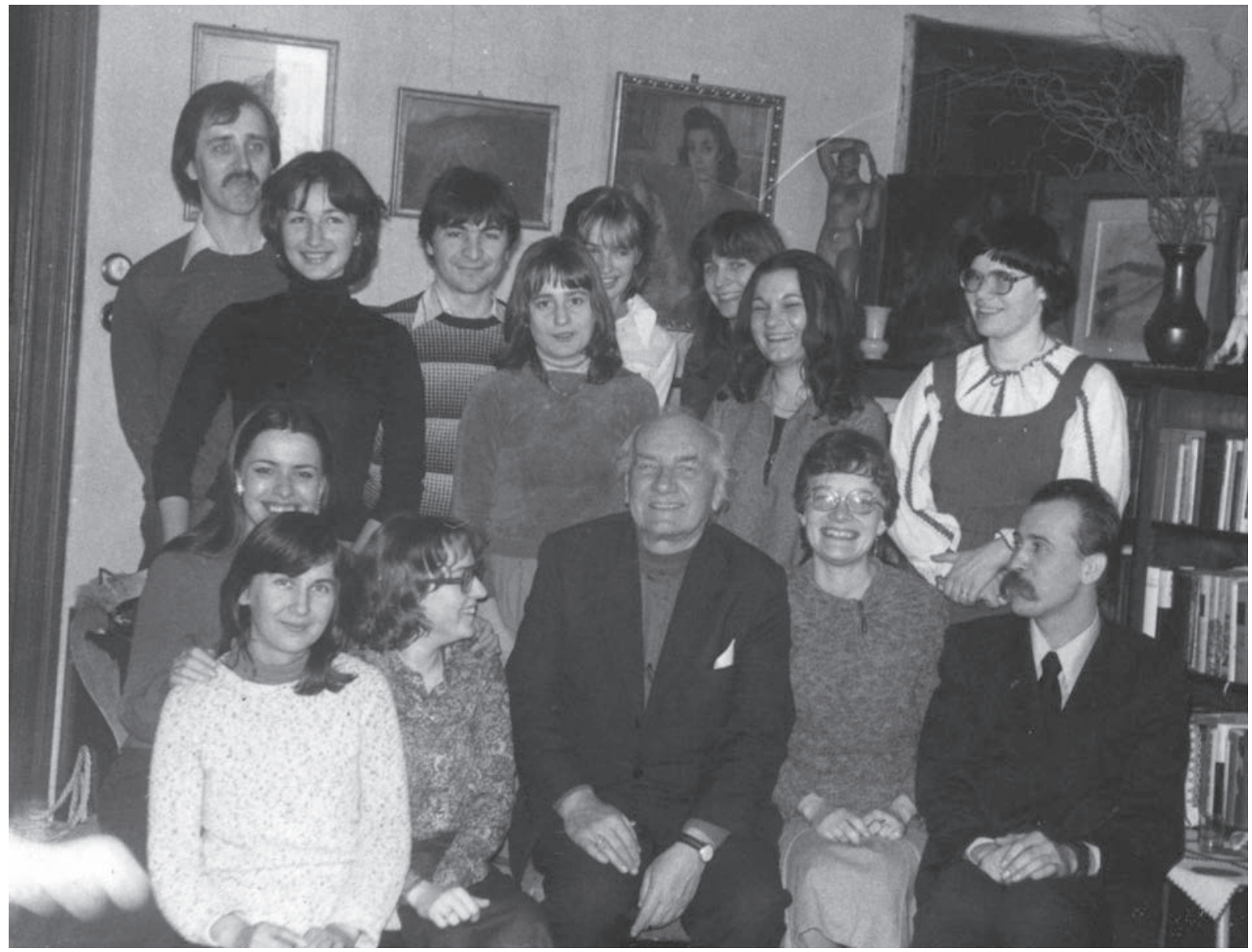

László Gyula V. évfolyamos tanítványai körében, 1980. március 13.

Hátsó sor: Michnai Attila, Szaniszlai József, Oravecz Hargita, Bellér Ildikó Középső sor: Kovács Gyöngyi, Bánffy Eszter, Torbágyi Melinda, Biró Katalin Első sor: Kovács-Borosi Ágnes, Gyuricza Anna, Marx Mária, László Gyula, Ottományi Katalin, Költő László 


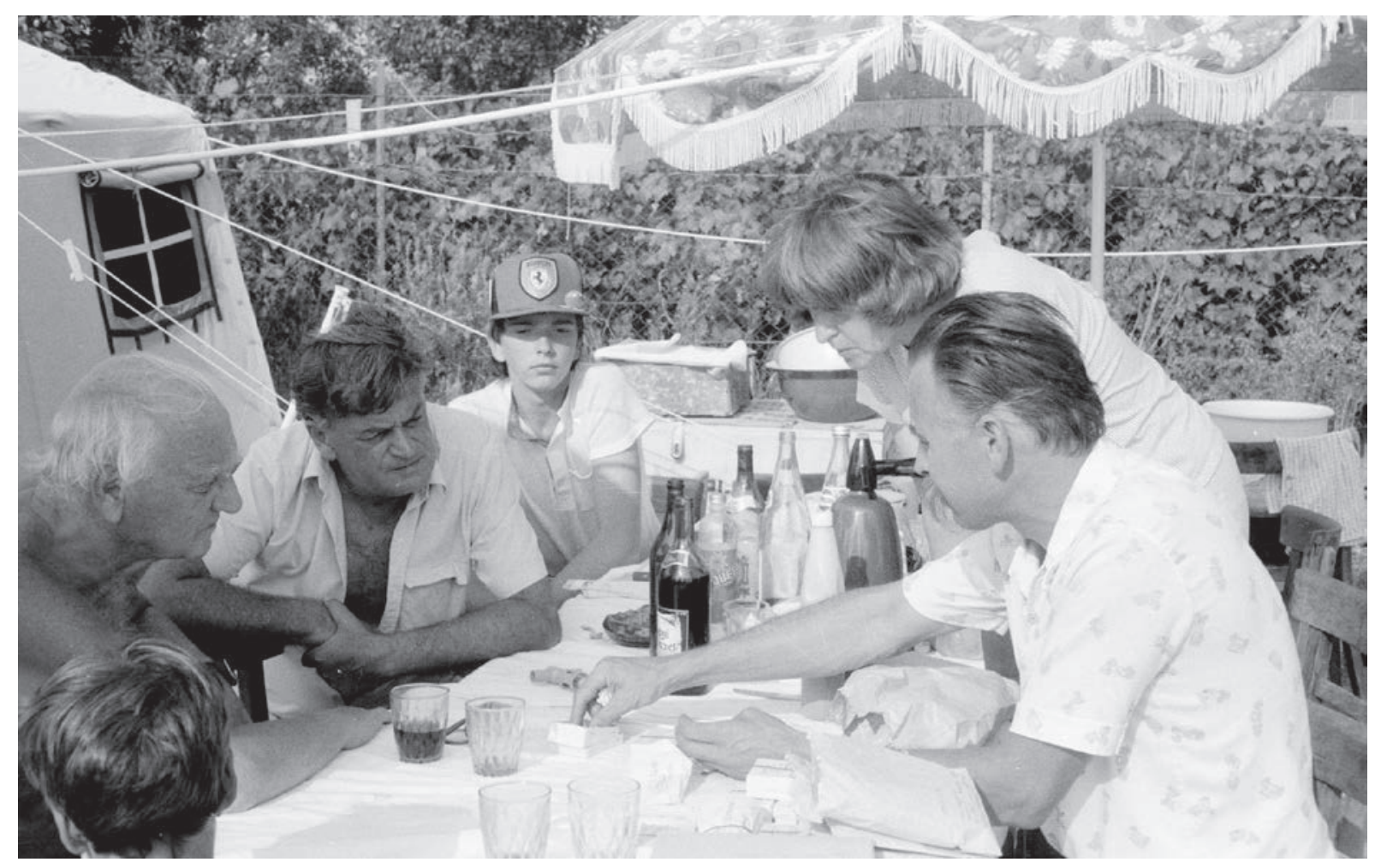

László Gyula, Bóna István, B. Horváth Jolán és Költő László a zamárdi ásatáson, 1980-as évek

(Bárdos Edith felvétele)

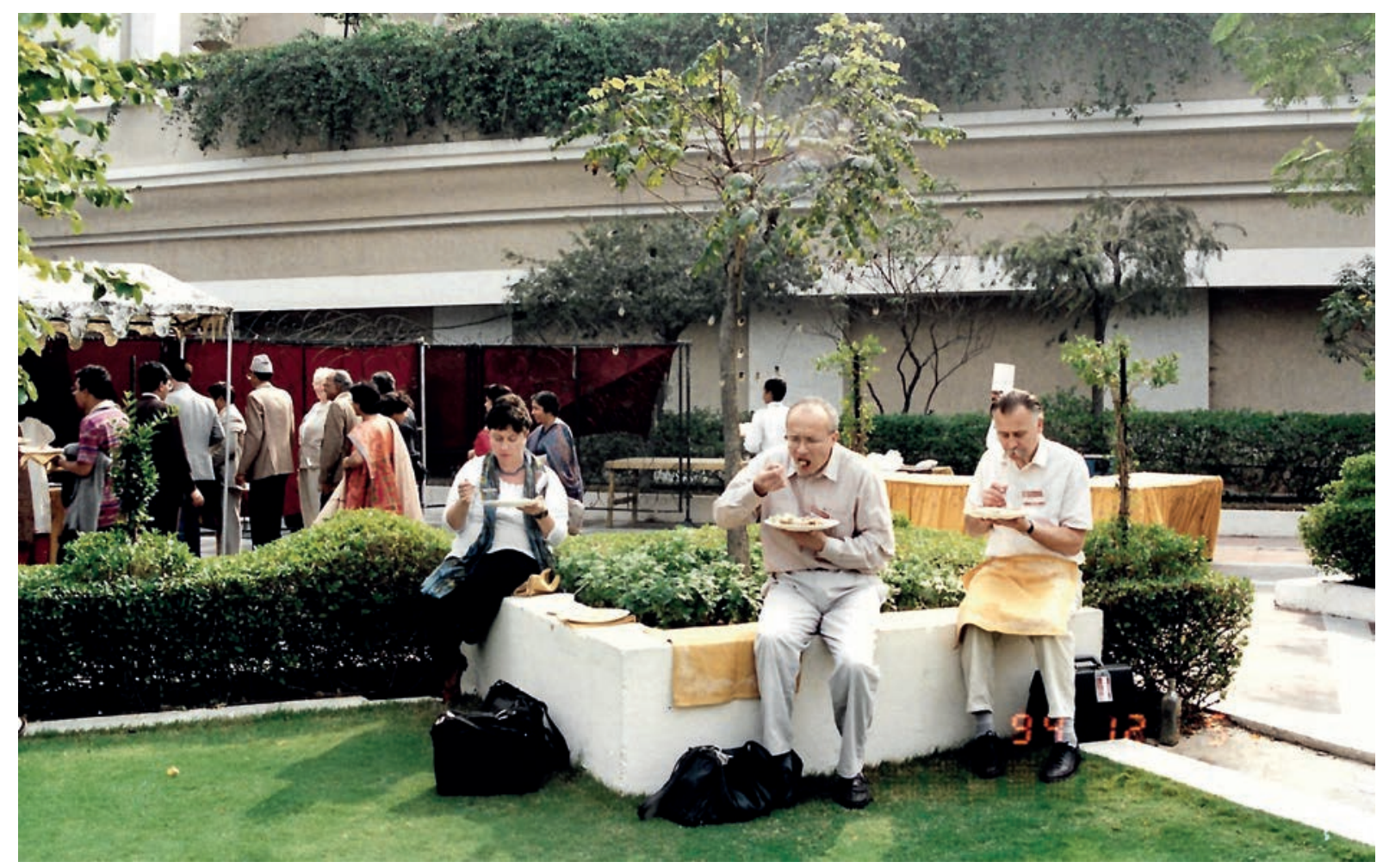

Csapó János és Költő László Új-Delhiben, 1994 


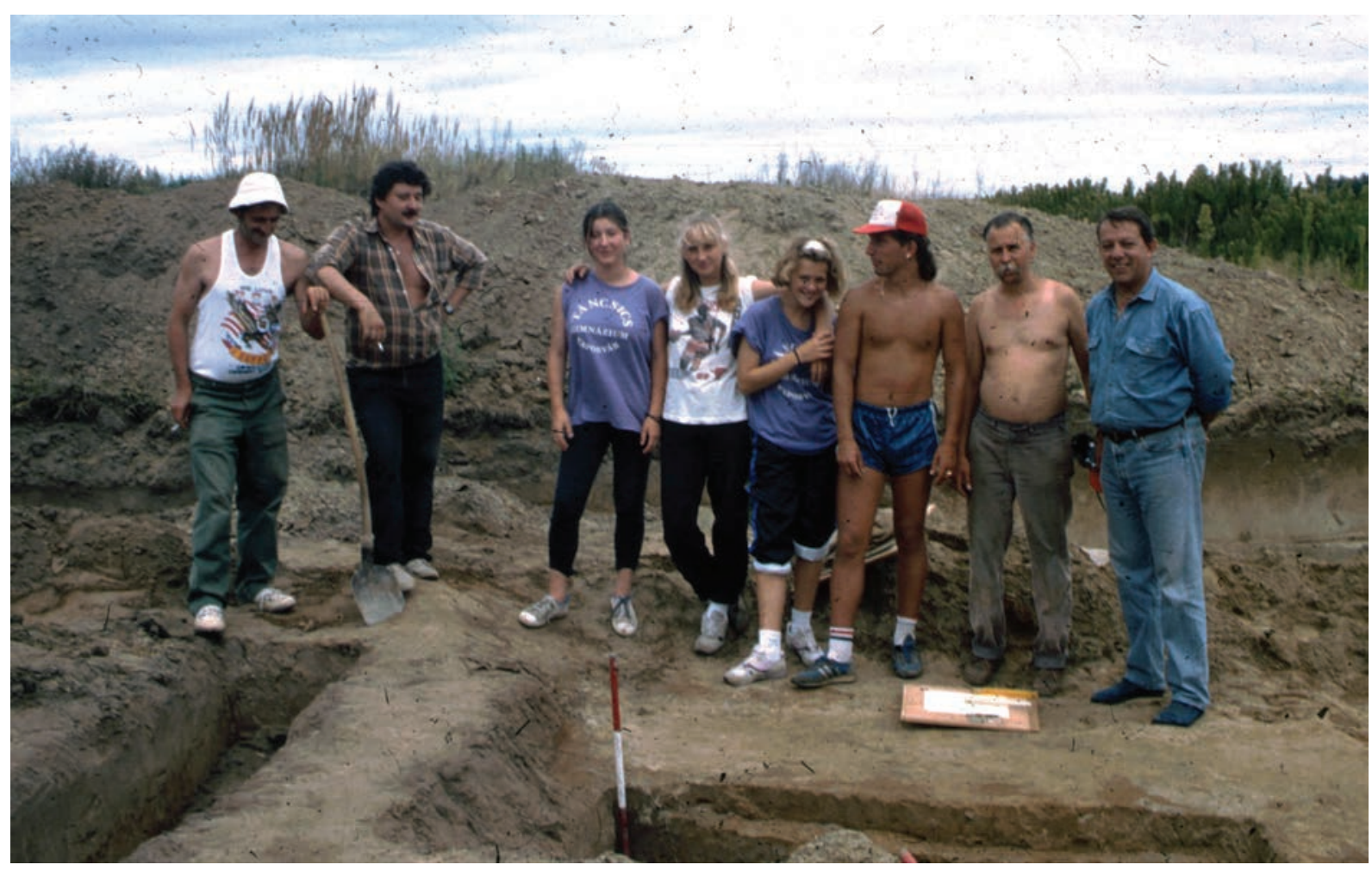

A vörs-papkerti ásatások, 1990-es évek

Tálos János, Gál Zoltán, Költő Orsolya és osztálytársnői, Nyári Zsolt, Költő László

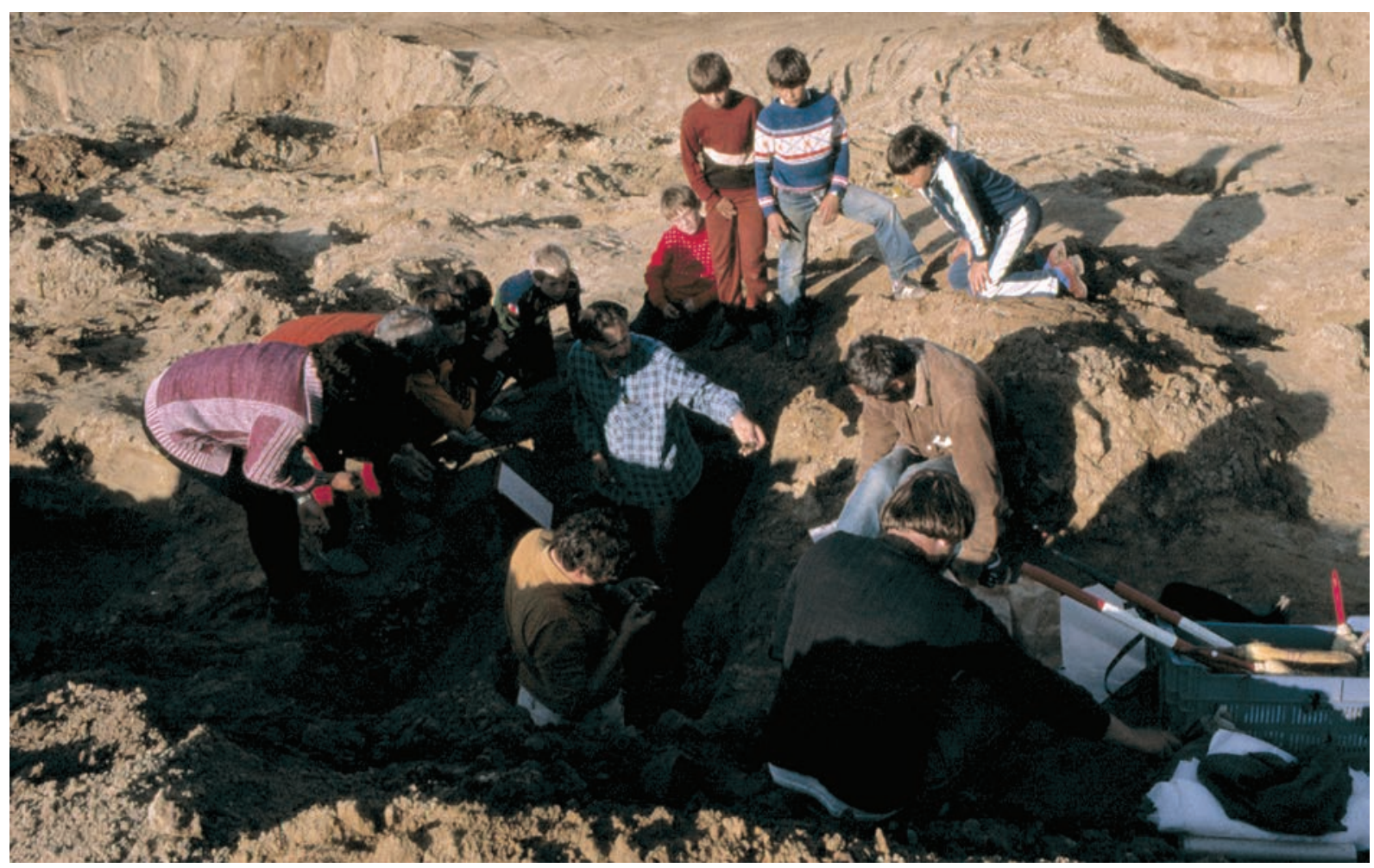

A vörs-papkerti ásatások, 1990-es évek 


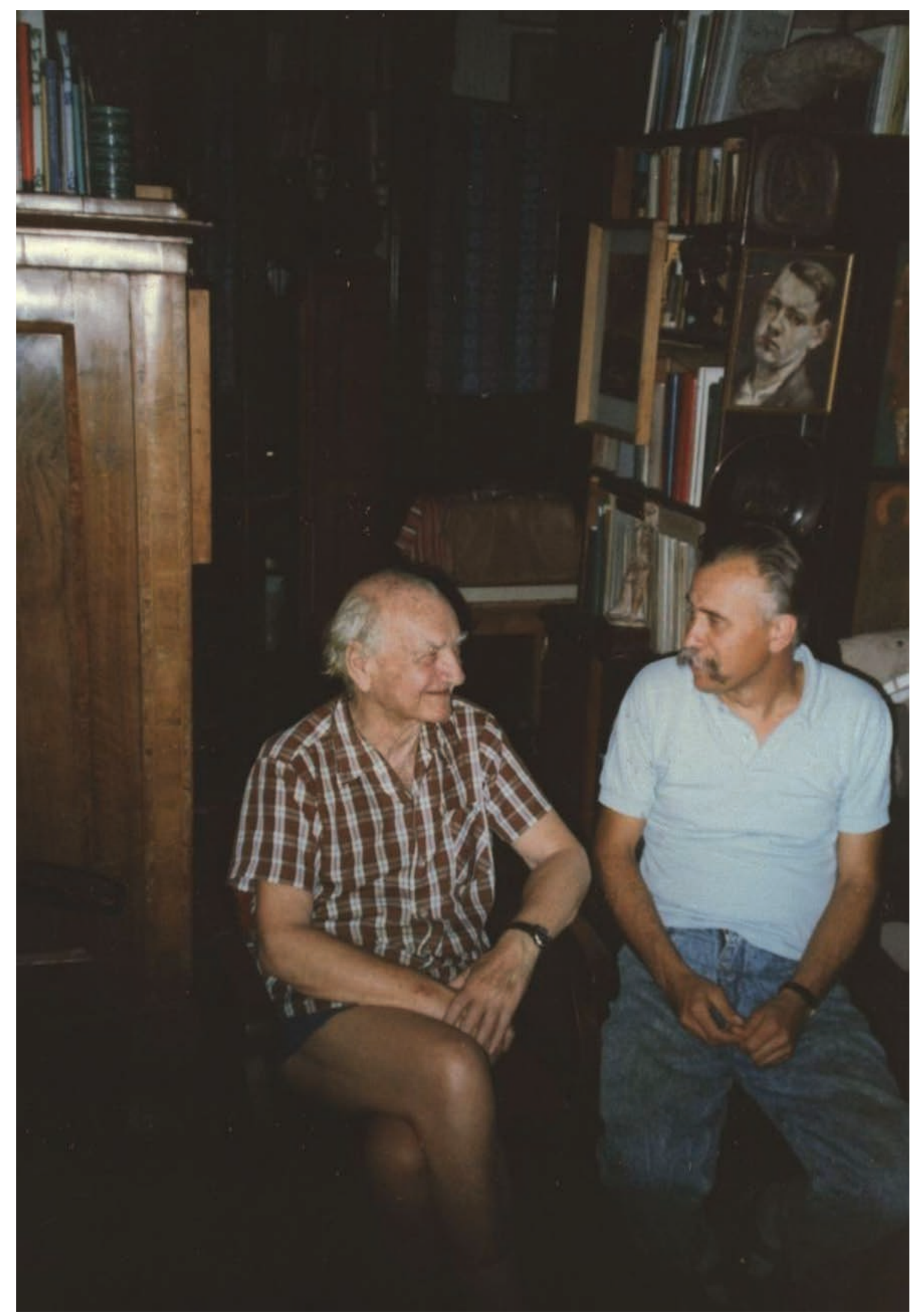

László Gyula és Költő László, 1991

(Szentpéteri József felvétele) 


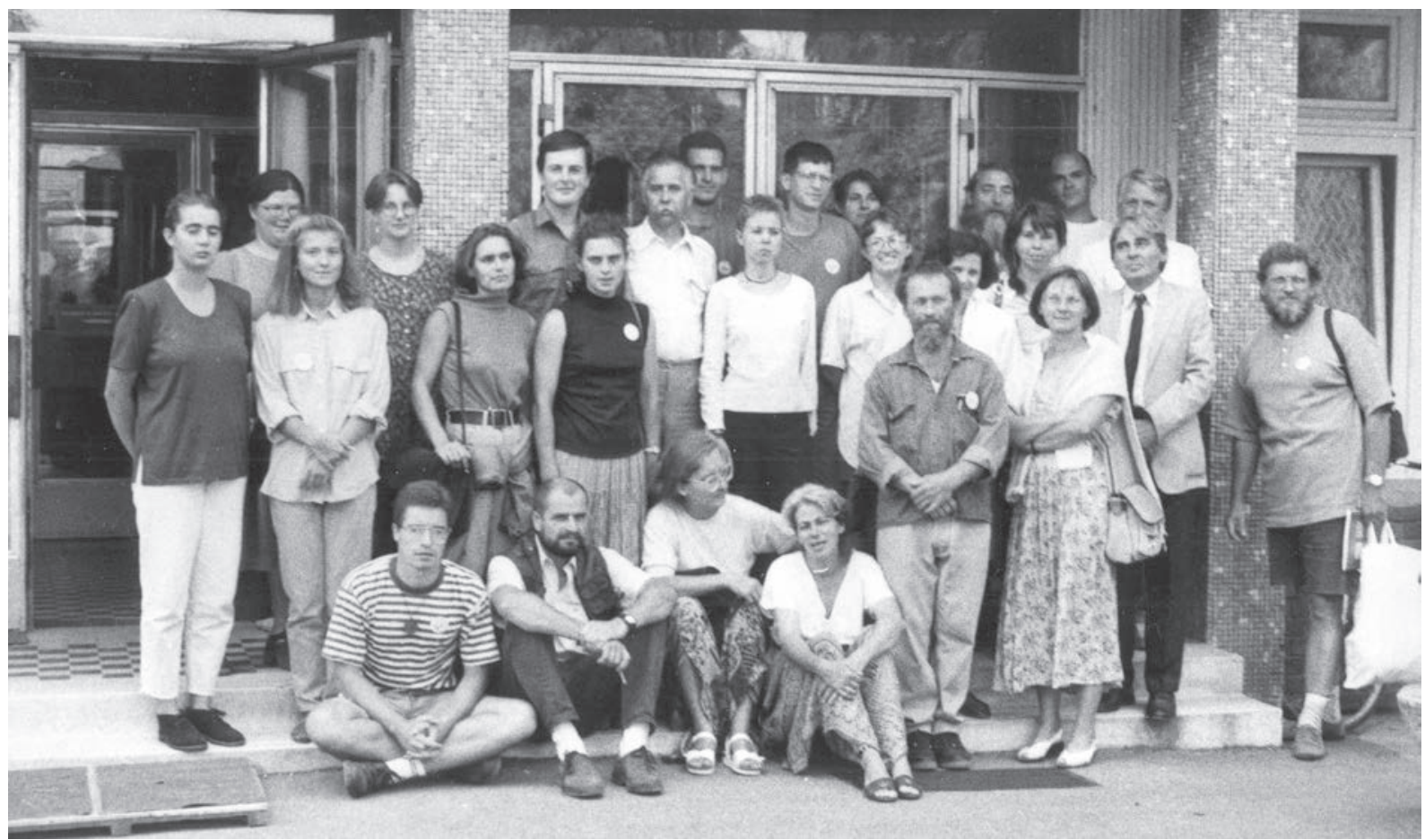

Bronzkor a Nyugat-Dunántúlon konferencia, Pápa, 1996. augusztus 26-28.

Leghátul: Tankó Károly, Havasi Bálint, ismeretlen, Ilon Gábor, V. Szabó Gábor, Torma István

Hátsó sor: T. Biró Katalin, Fischl Klára, Paul McLean, Költő László, ismeretlen, Talabér Tünde, Regenye Judit, Cseh Julianna, Kovács Tibor, ismeretlen

Ülök mögötti álló sor: Kulcsár Gabriella, Kiss Viktória, Torma Andrea, Farkas Csilla Ülő sor: Szilas Gábor, Szabó Géza, Honti Szilvia, Marton Erzsébet, mellettük állnak: Figler András, Somogyvári Ágnes

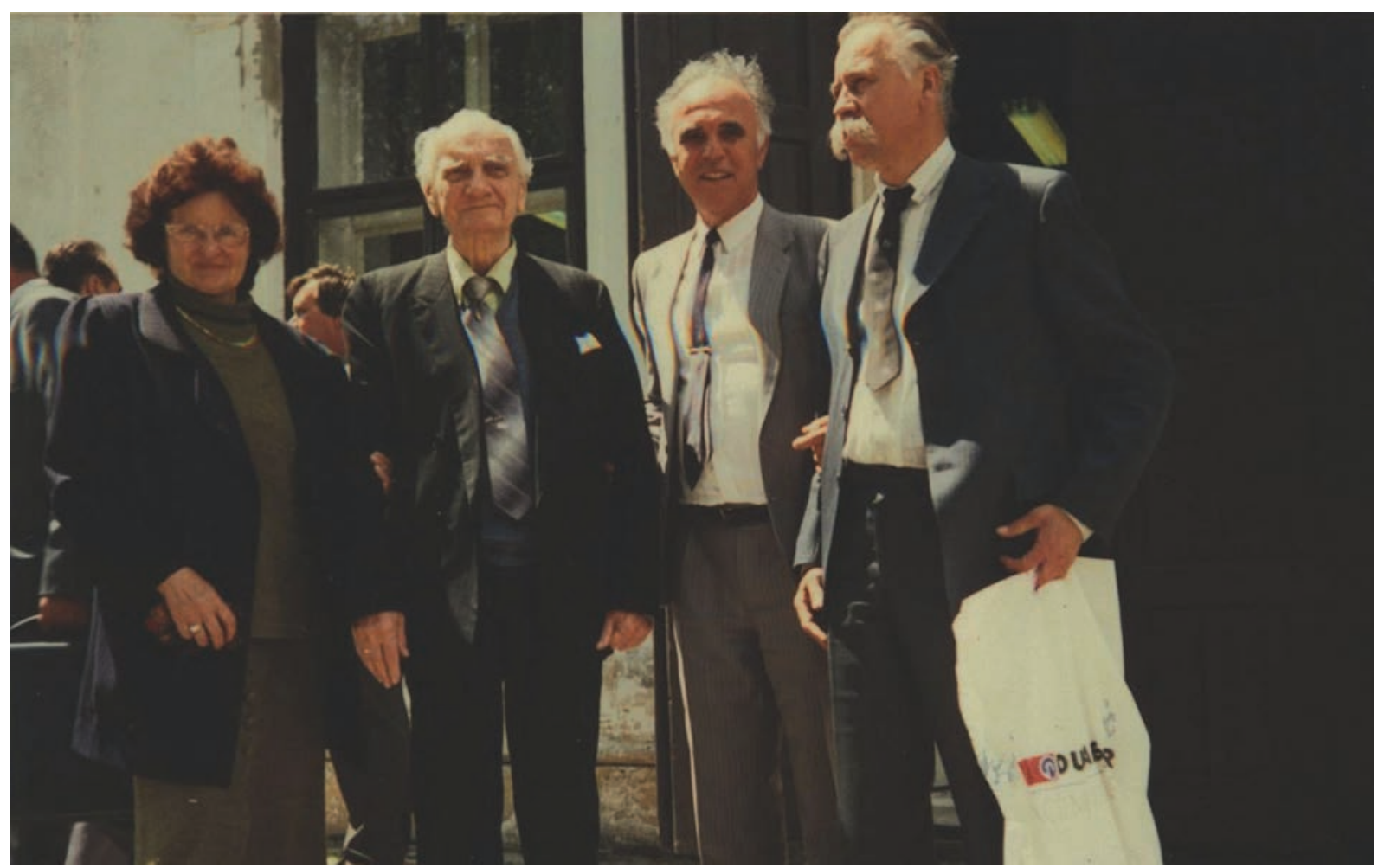

László Gyula, Stamler Imre és Költö László Somogyfajszon, 1997 


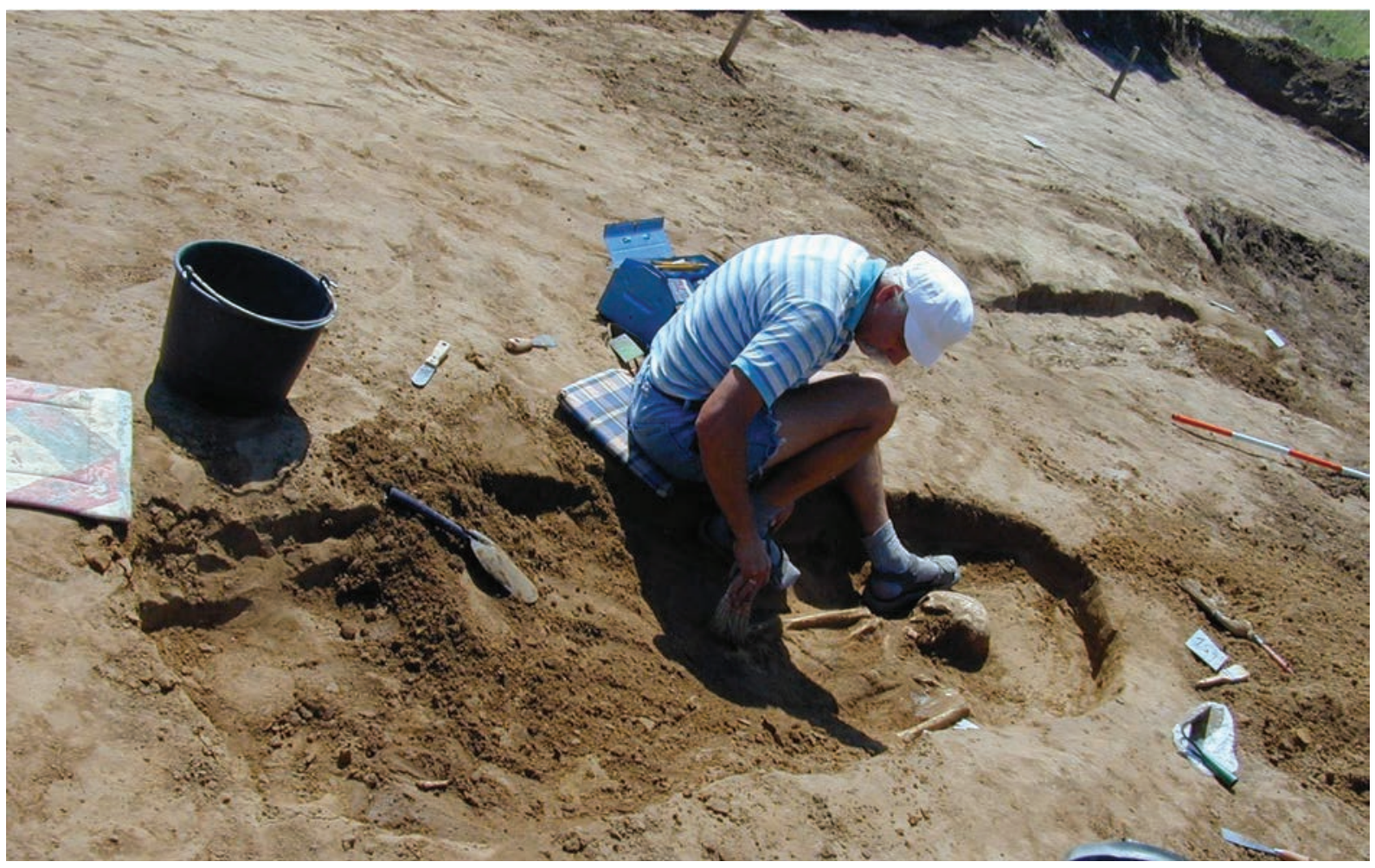

Költő László Vörs-Majori-dűlő ásatásán, 2001

(Bernert Zsolt felvétele)

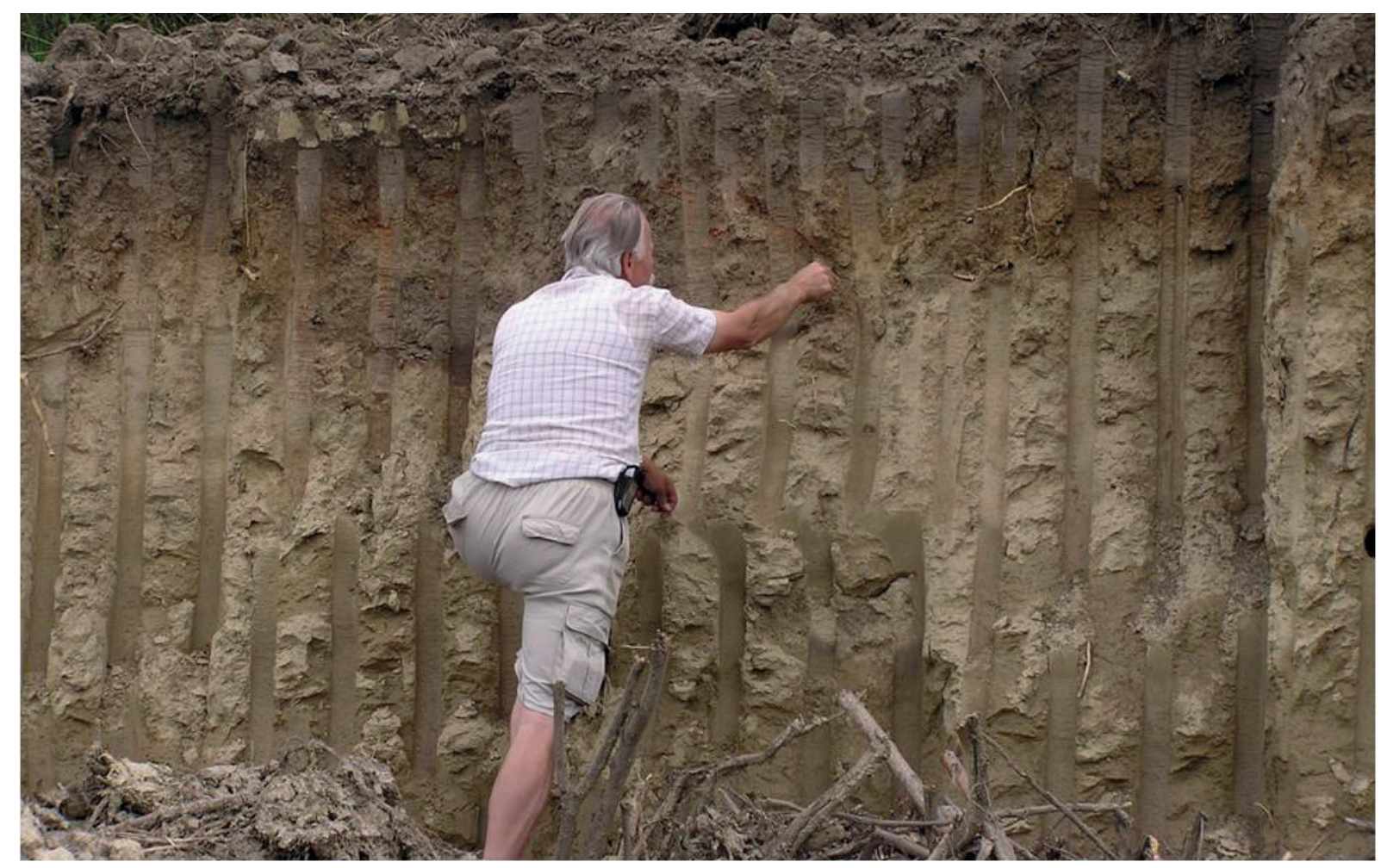

Költő László a patalomi leletmentésen, 2005 (Aradi Csilla felvétele) 


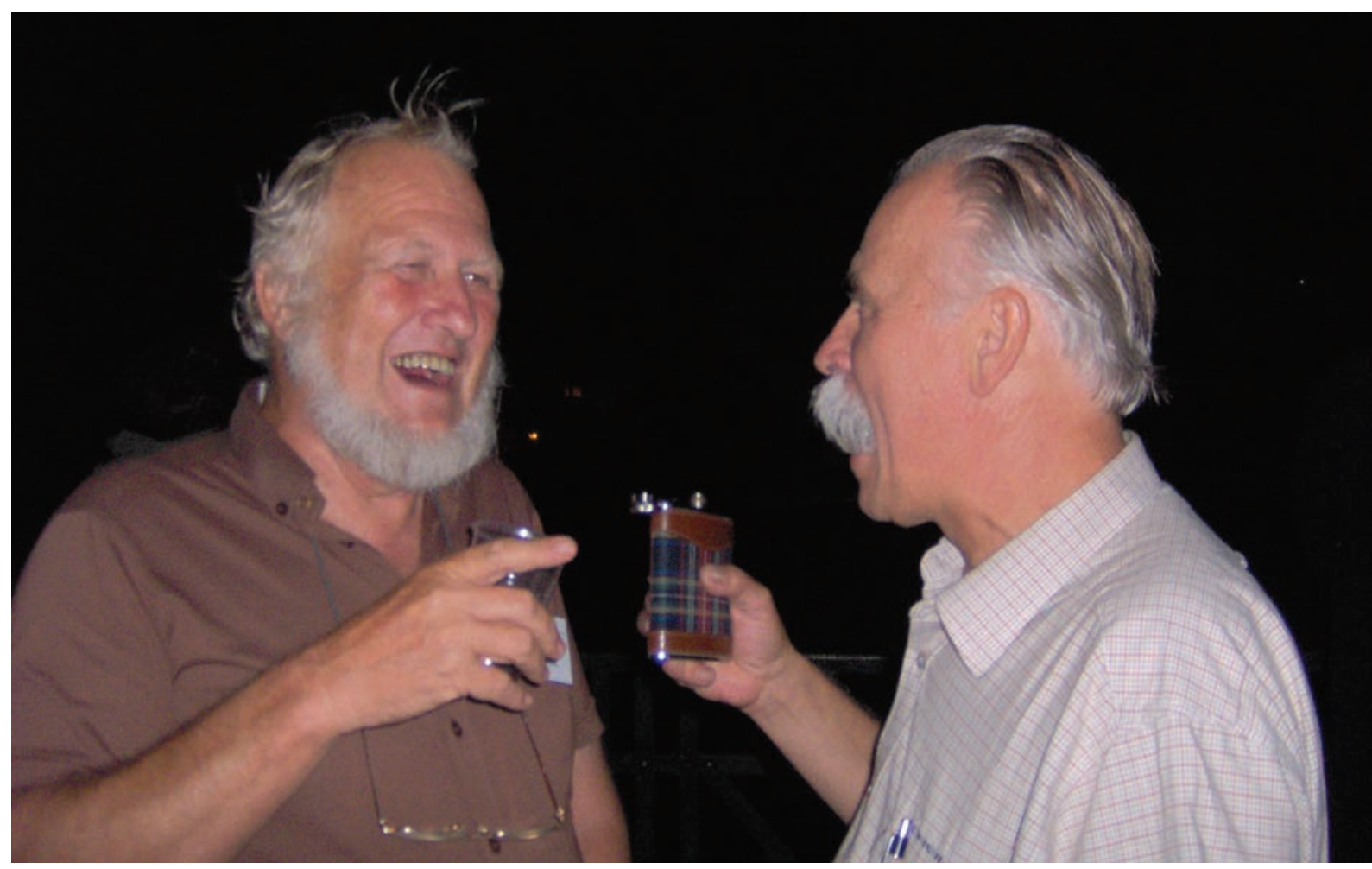

Tomka Péter és Költö László a XVII. Hadak Útja konferencián Nagyváradon, 2006 (Tóth Gábor felvétele)

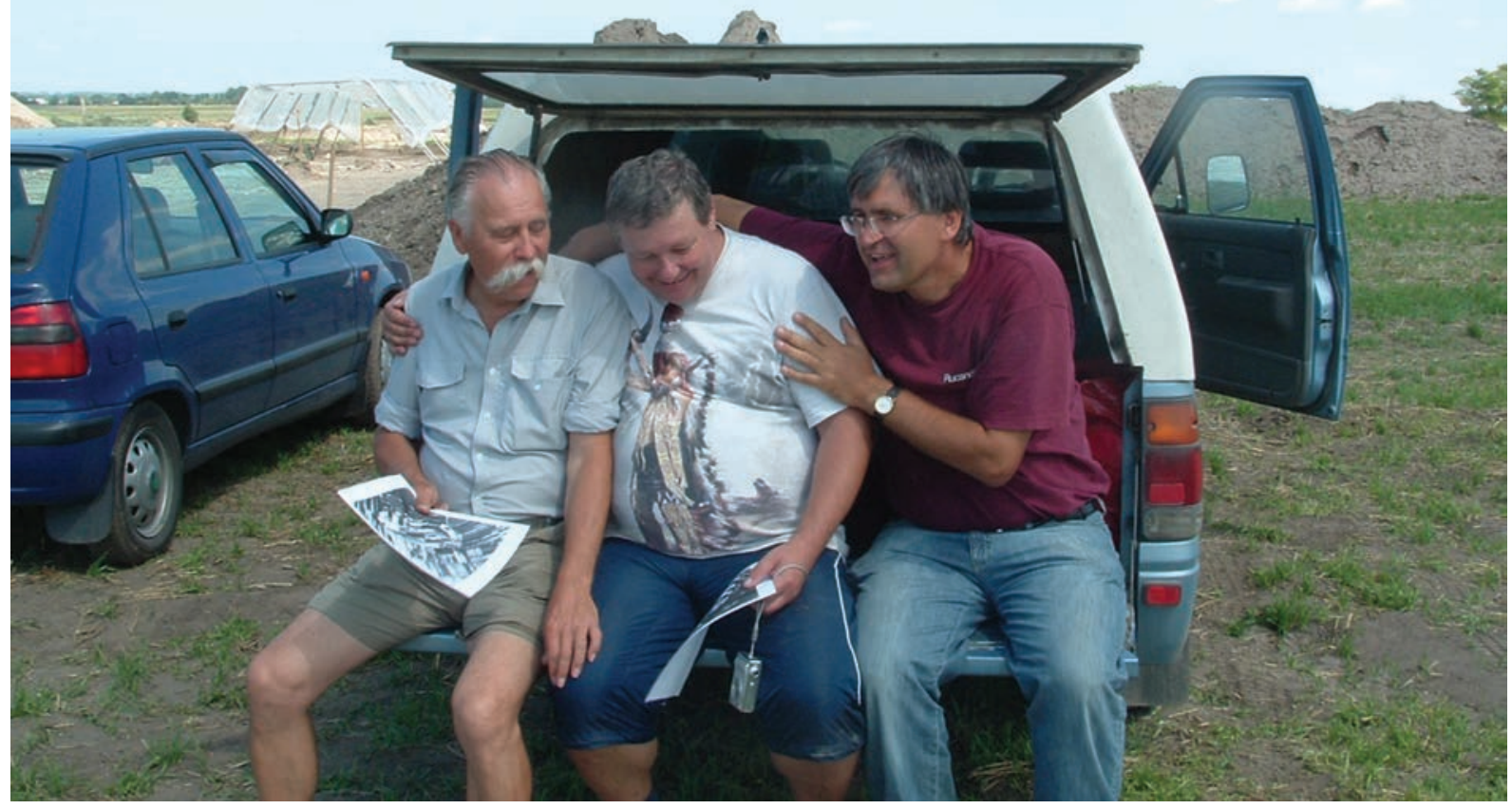

Költő László, Madaras László és Szentpéteri József a solt-tételhegyi ásatáson, 2006 (Madaras Lászlóné felvétele) 


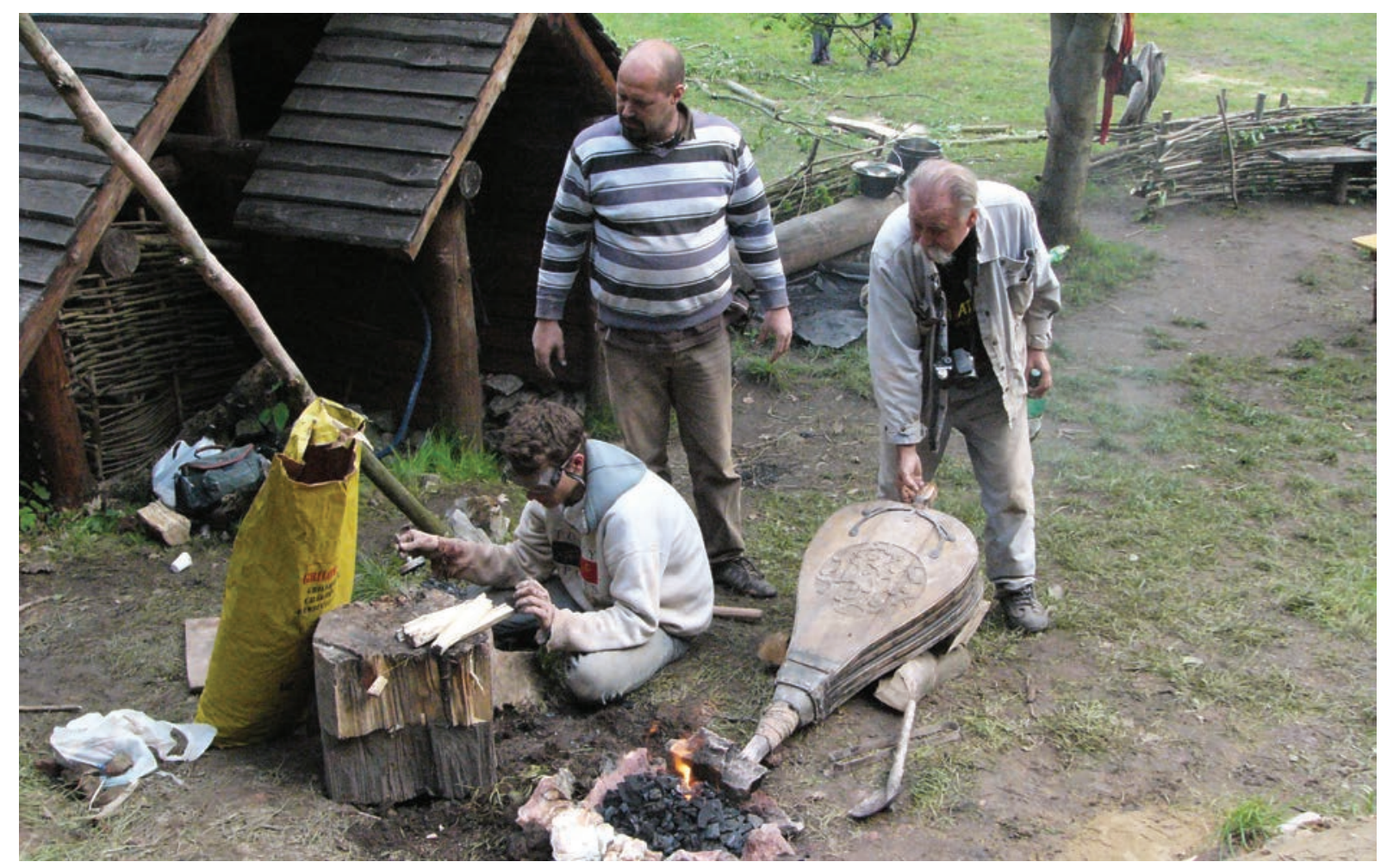

Kisérleti bucavas kohászat Adamovban, 2010

Thiele Ádám, Gallina Zsolt, Költő László

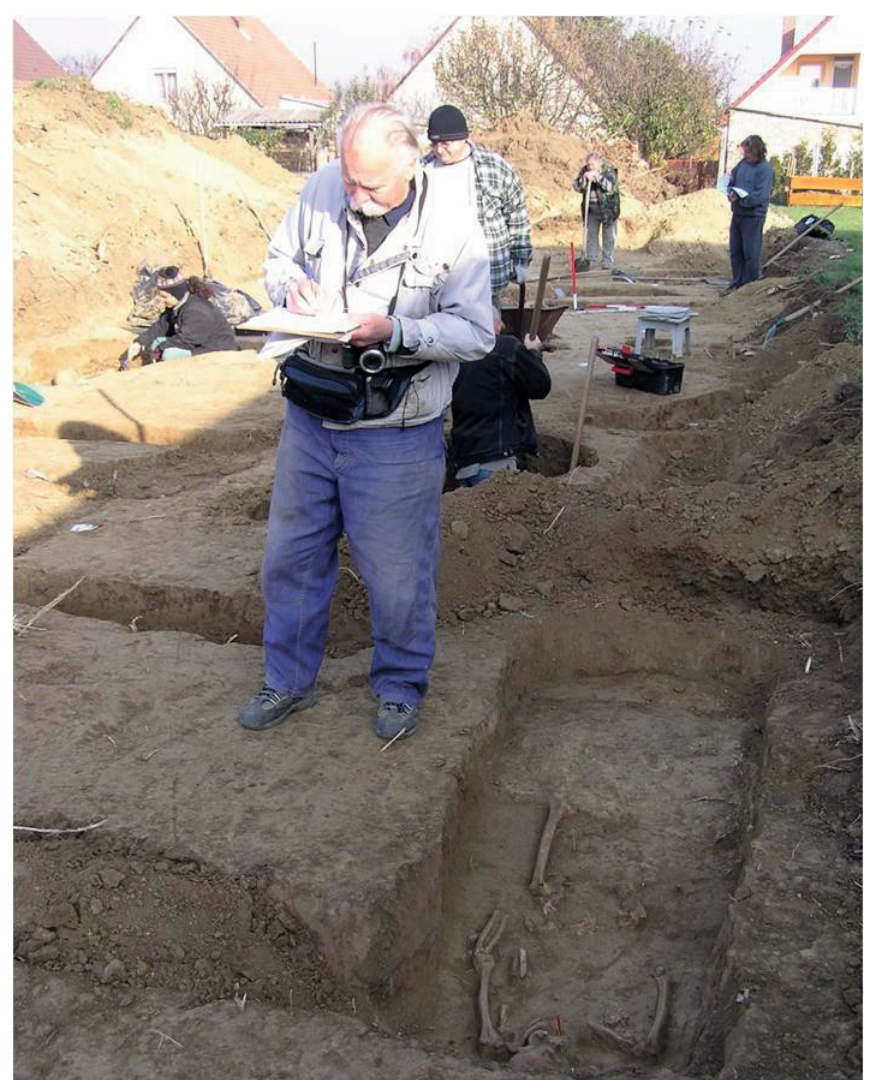

Költő László a kaposvár-kertészeti ásatáson, 2011

(Aradi Csilla felvétele) 


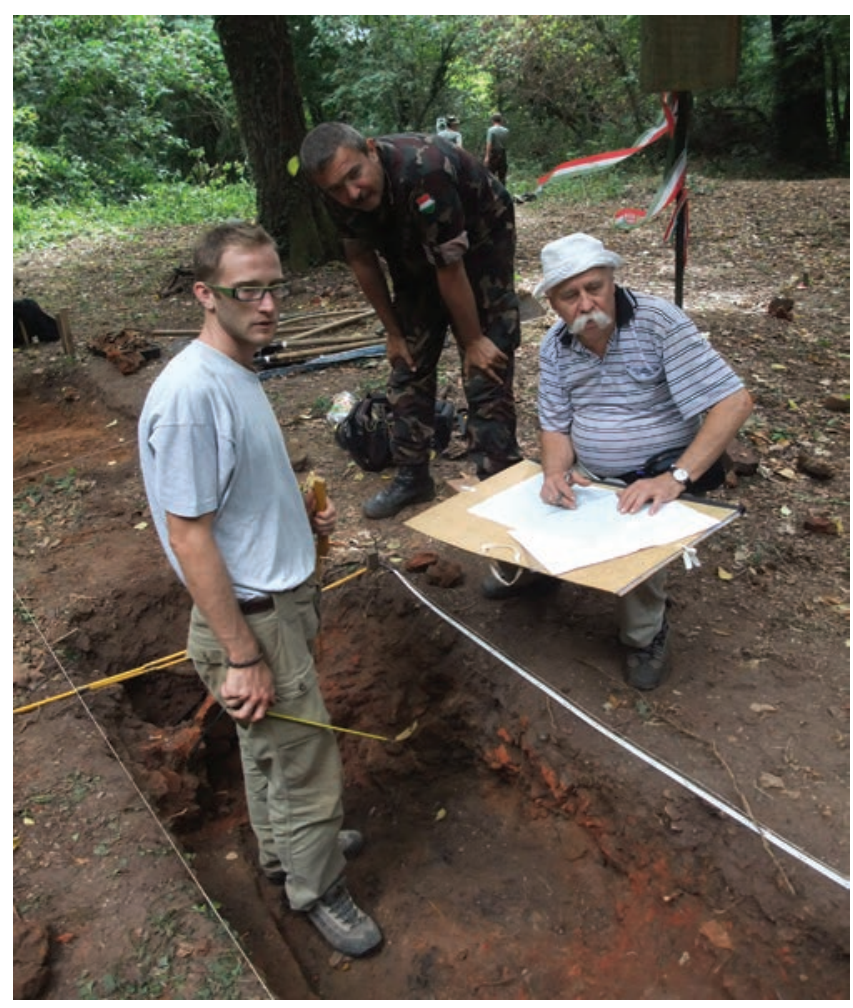

Varga Máté, Négyesi Lajos és Költő László elmélkednek a zrínyi-újvári ásatáson, 2011

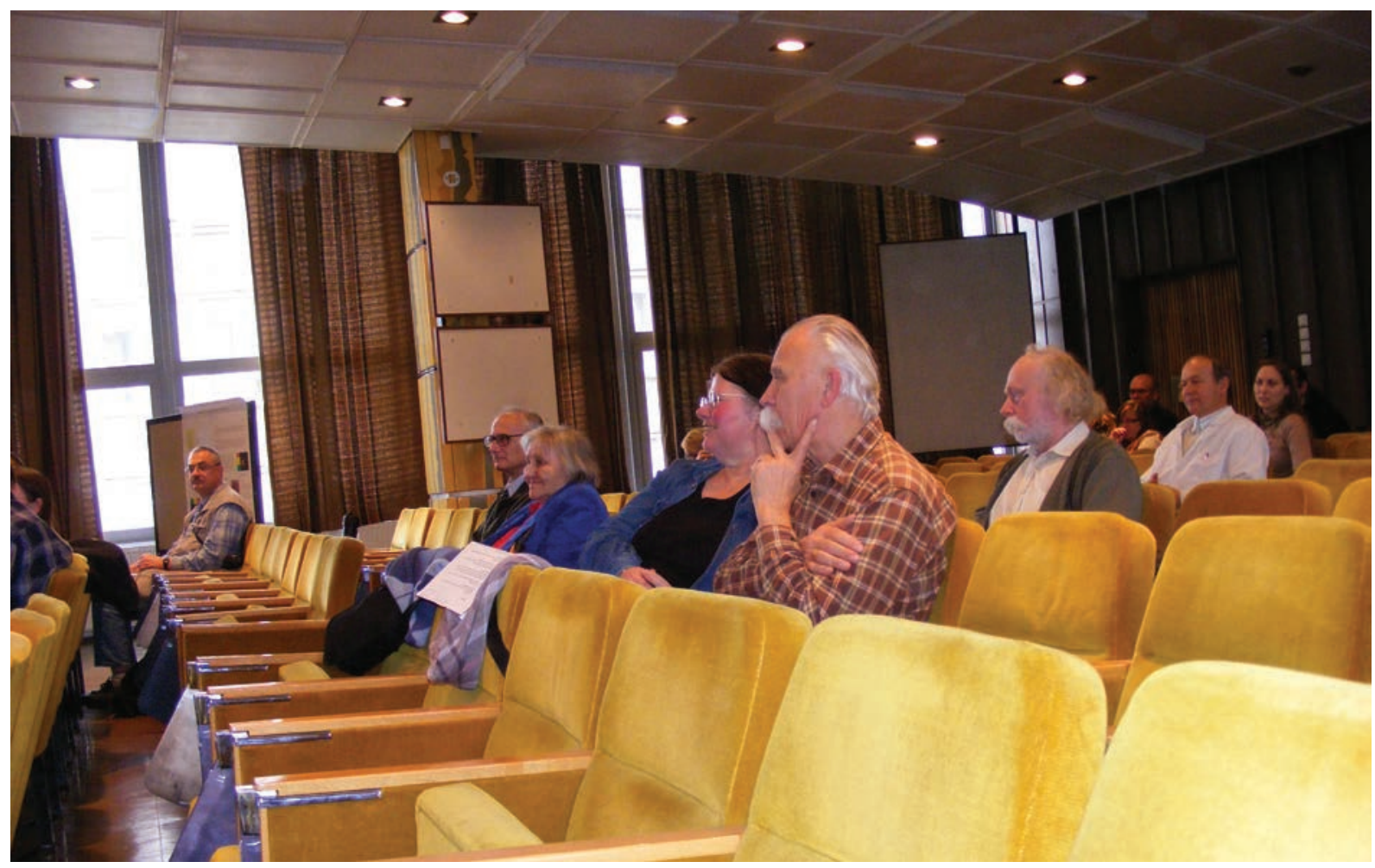

T. Biró Katalin és Költő László az Archeometriai Albizottság ülésén, 2012 (Tóth Mária felvétele) 


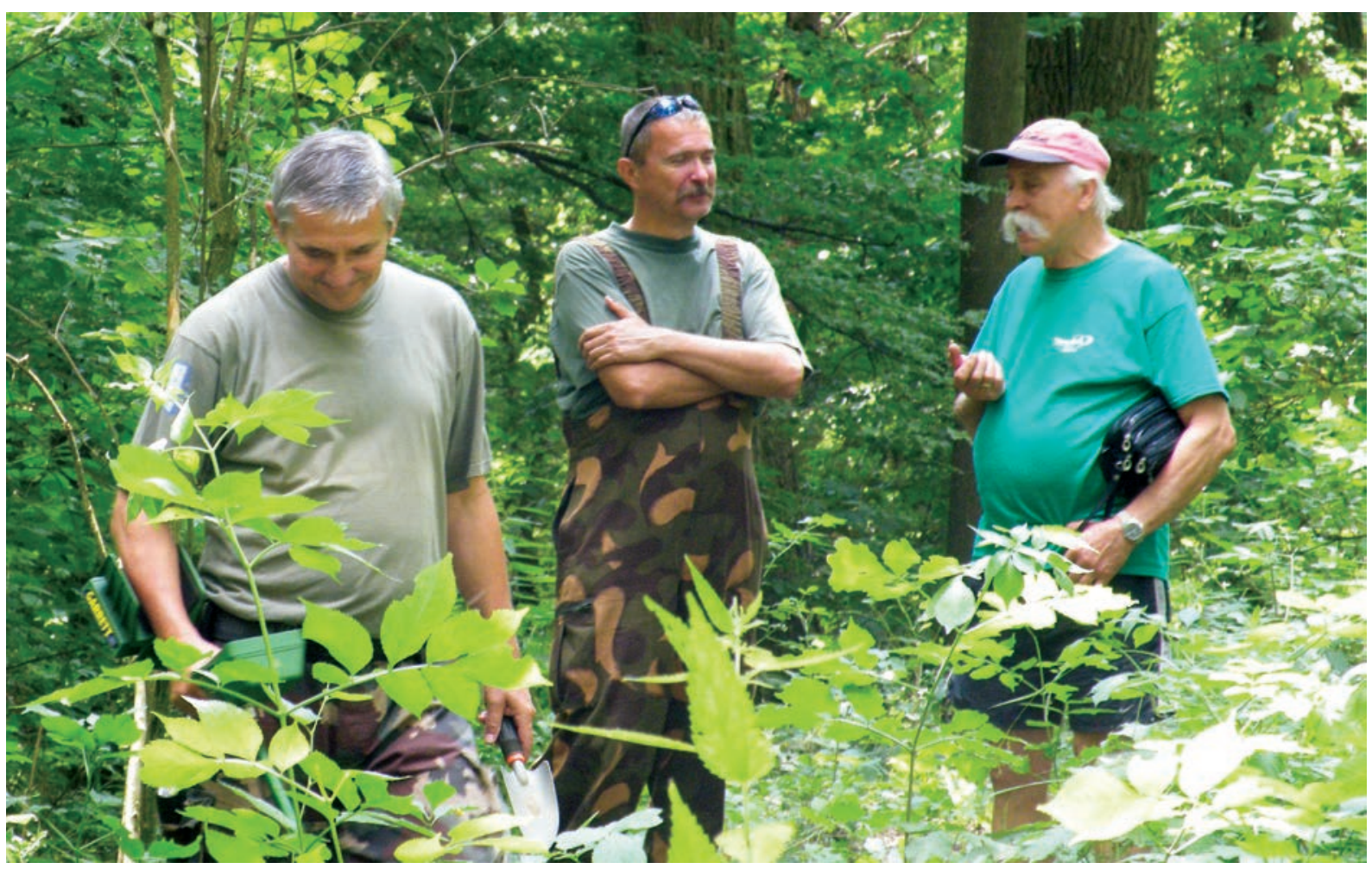

Padányi József, Négyesi Lajos és Költő László zrínyi-újvári leletfelderítésen, 2013 (Varga Máté felvétele)

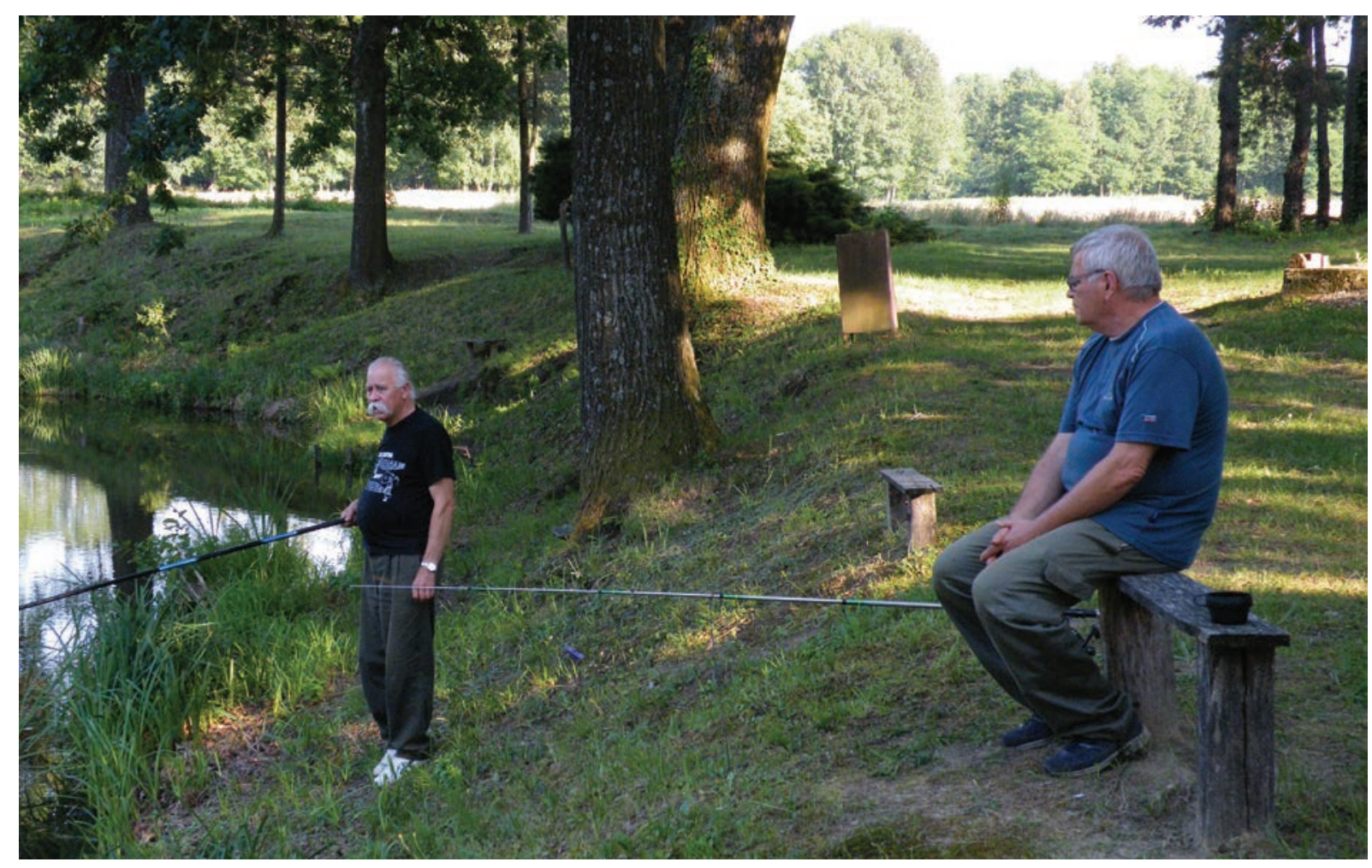

Lazítás a beleznai halastavon, Zrínyi-Újvár után, 2013, Költő László és Vándor László (Varga Máté felvétele) 


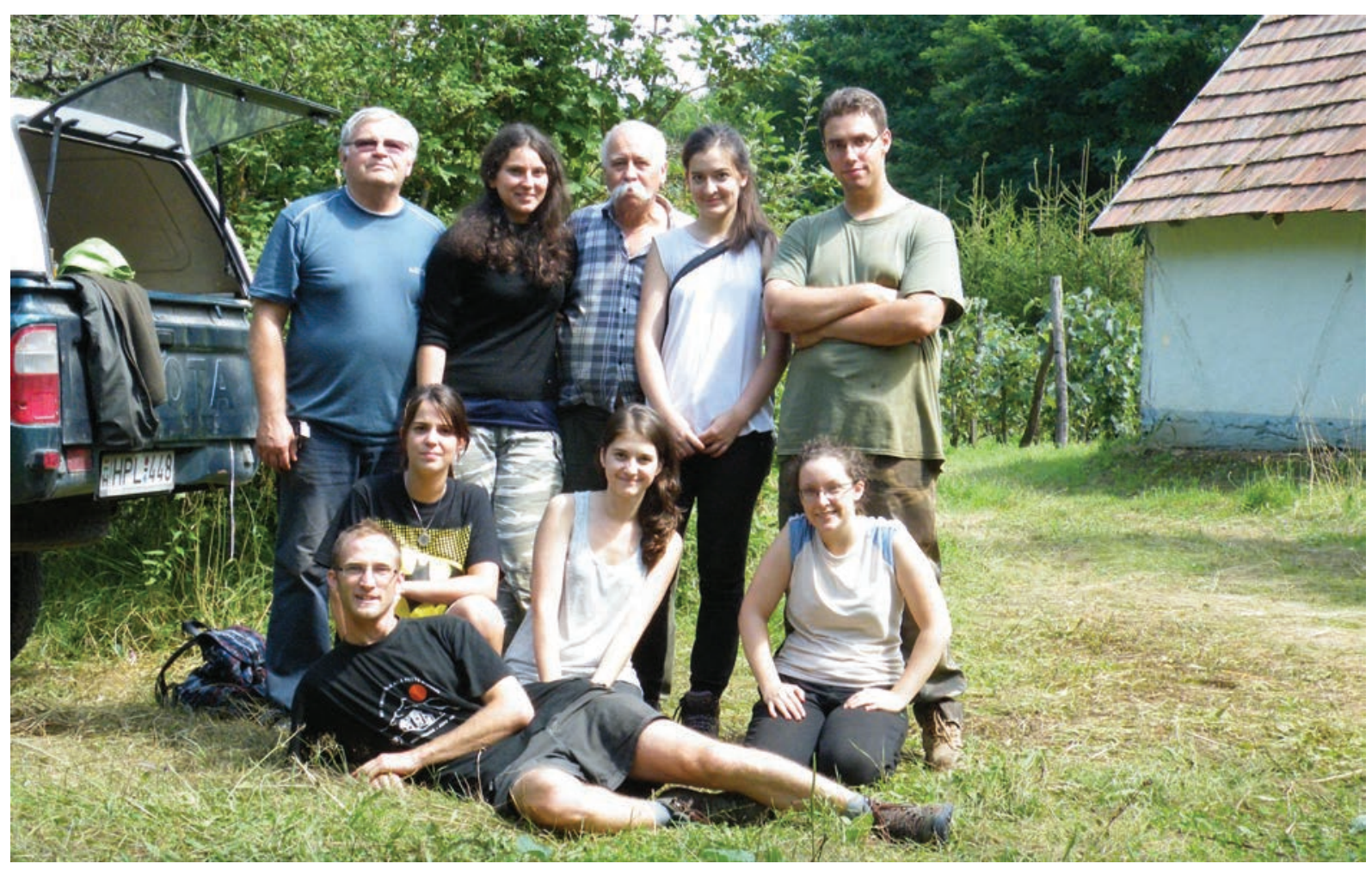

Zrínyi-Újvár ásatásán, 2014

Vándor László, Szász Barbara, Költő László, Kovács Szabina, Harag Mátyás, Parczen Anna, Molnár Karola, Szűcs Flóra, Varga Máté

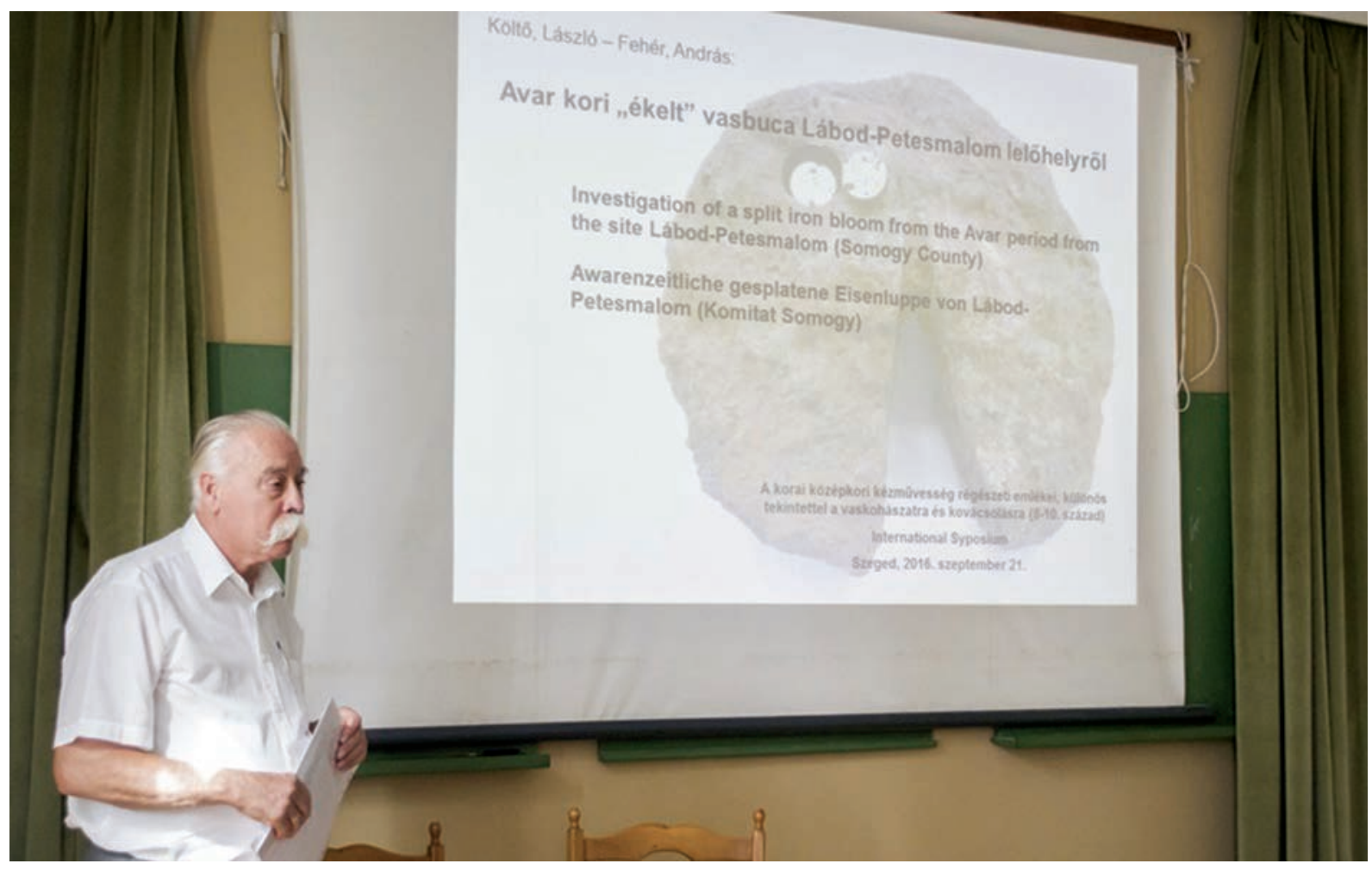

Költő László a szegedi szimpóziumon, 2016

(Walter Réka felvétele) 


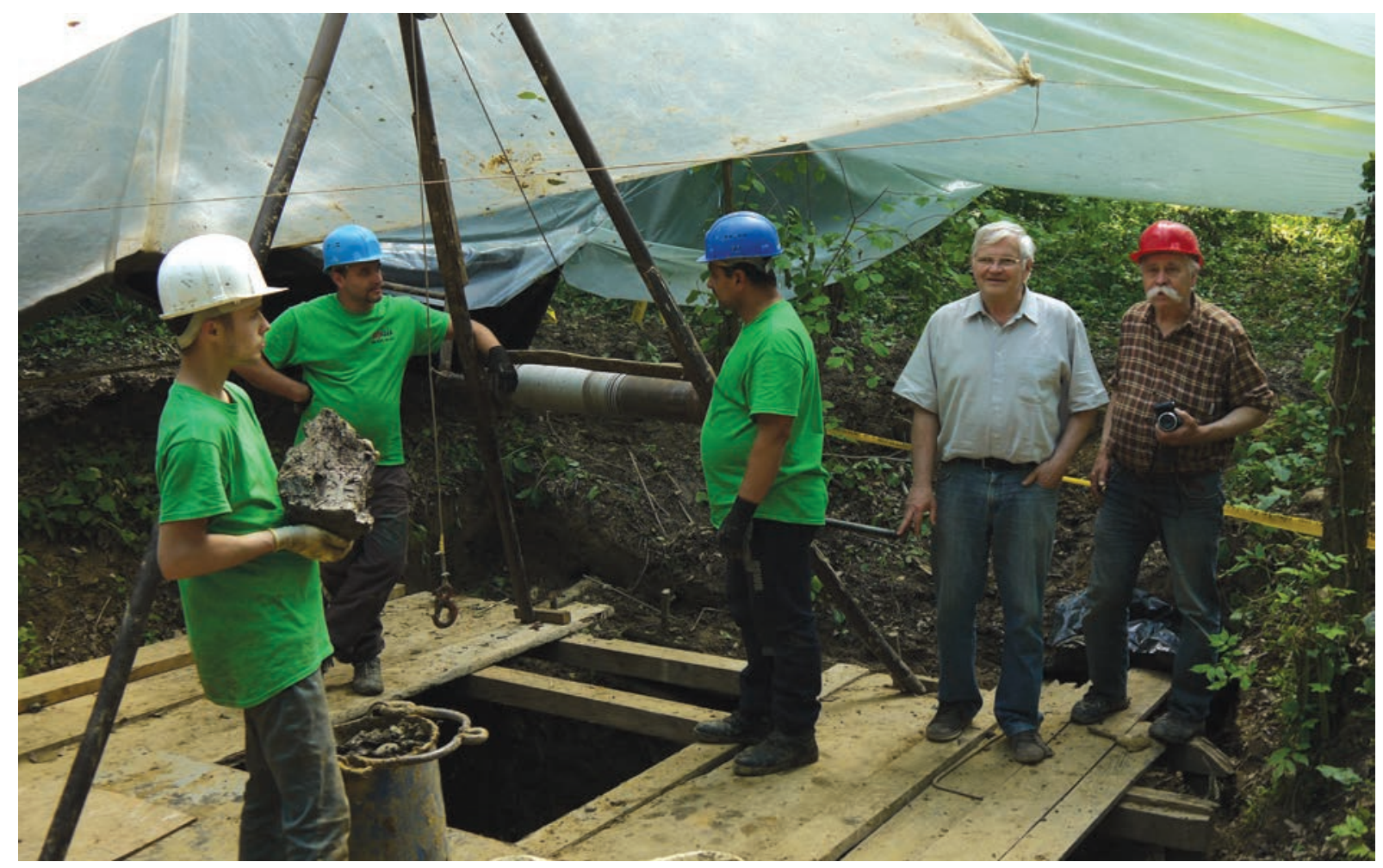

Zrínyi-Újvár kútjának feltárása, 2017

A kútásók csapata: Suller Ákos, Tóth Balázs, Bogdán János, Vándor László és Költő László

(Varga Máté felvétele)

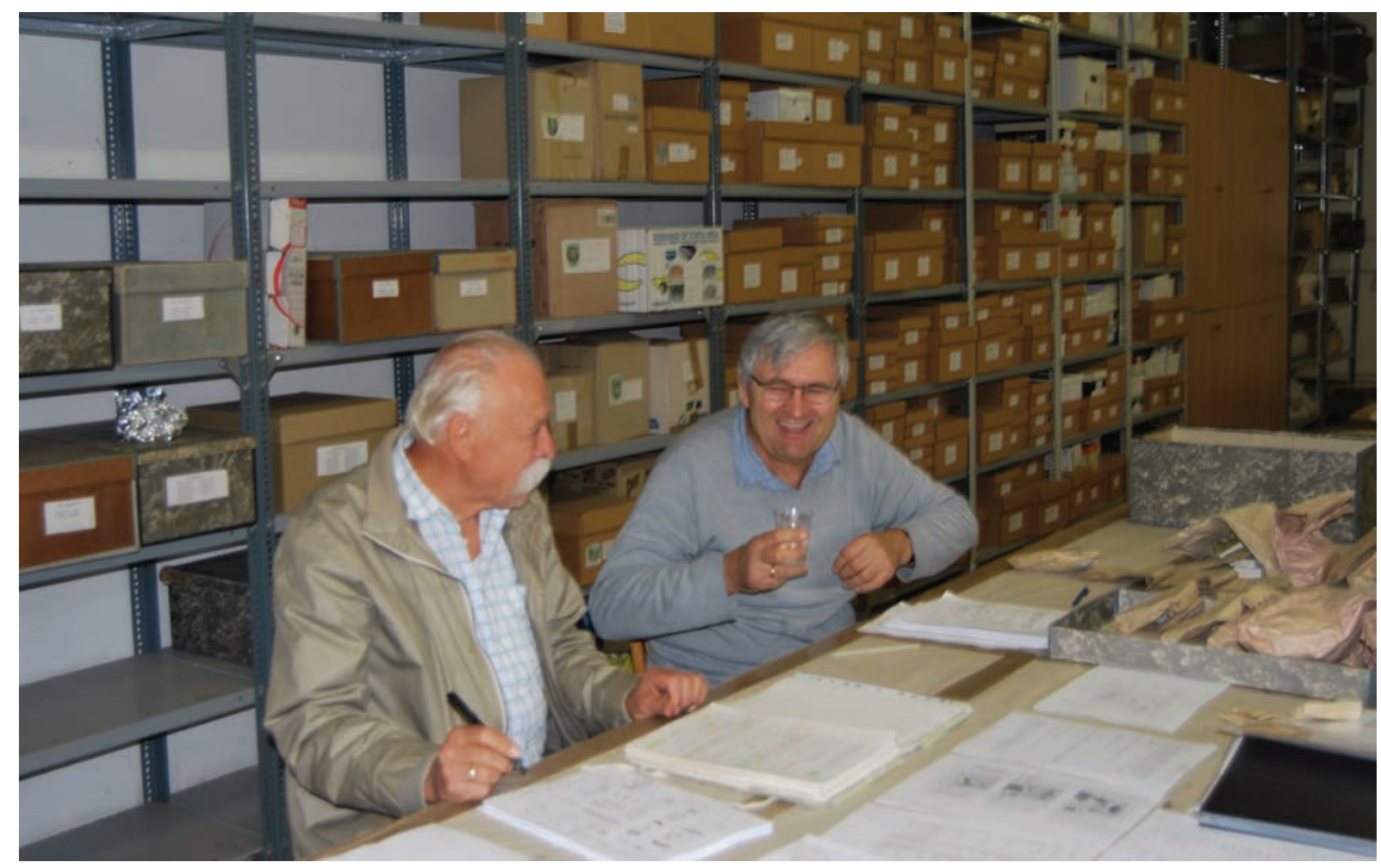

Költő László és Szentpéteri József a vörs-papkerti leletanyag feldolgozása közben Kaposváron, 2018 (Baksics Gábor felvétele) 


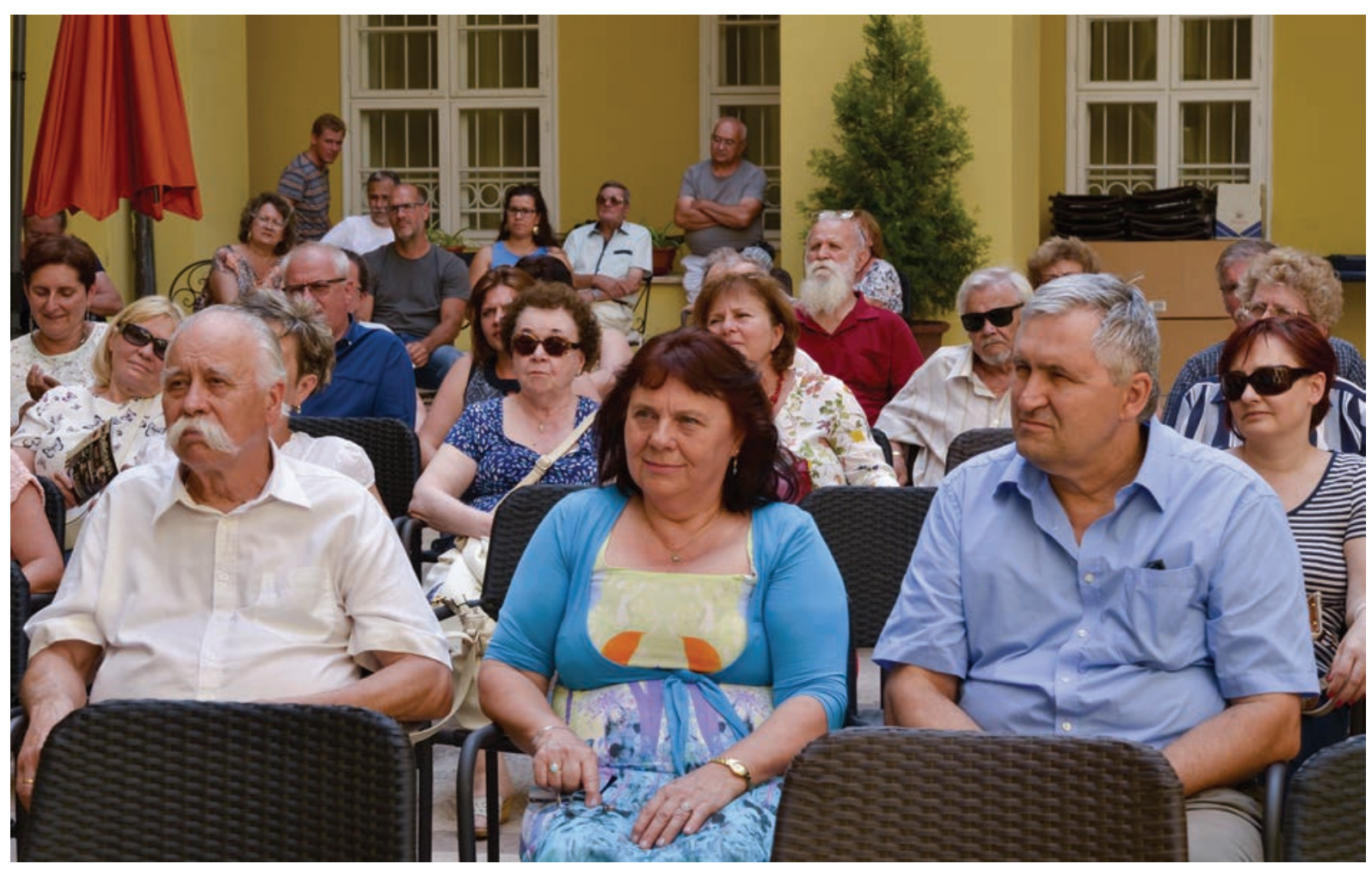

Költő László, Madaras Lászlóné és Szentpéteri József Szolnokon, 2018 (Madaras László felvétele)

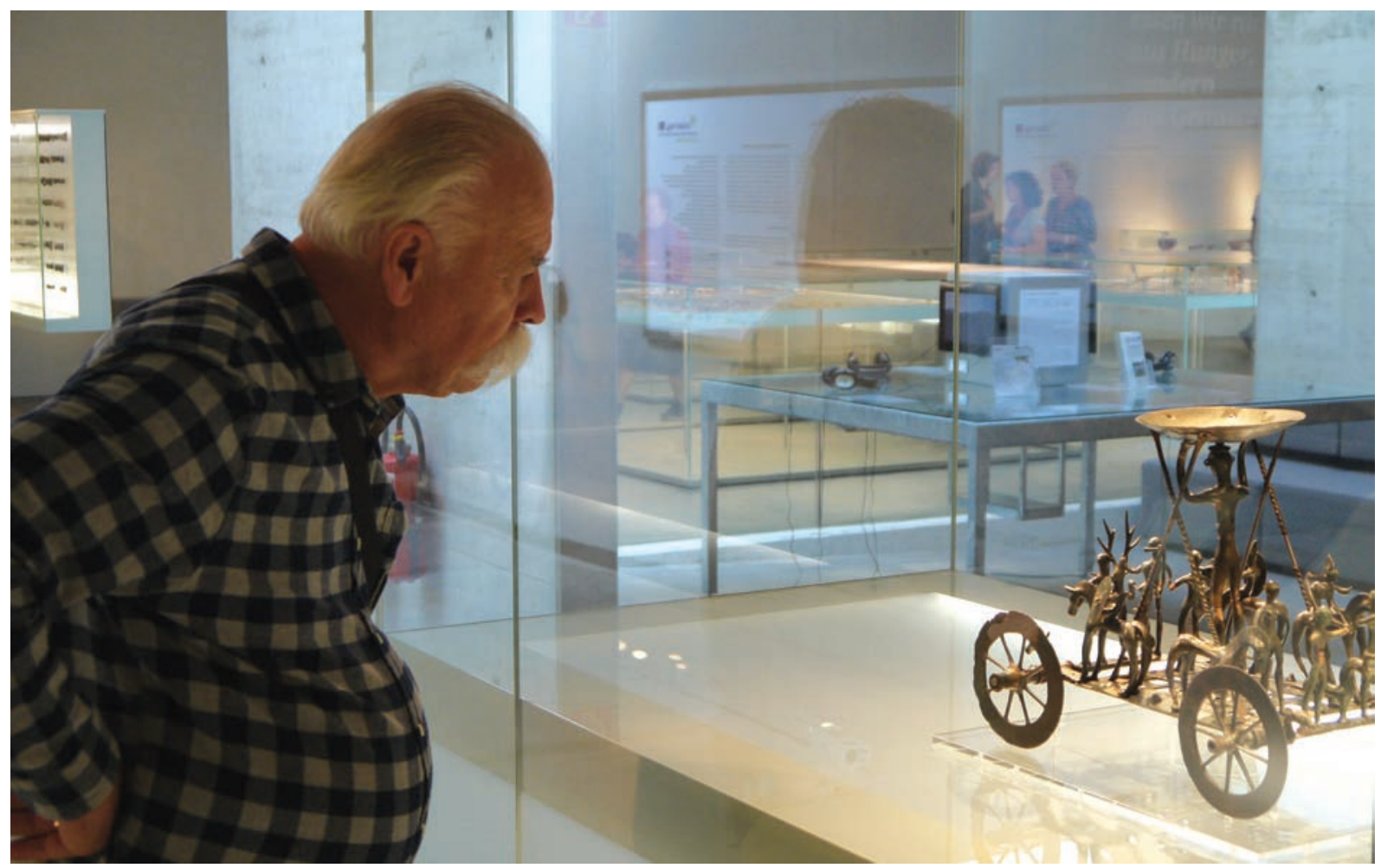

Múzeumi szakmai kiránduláson Grazban, 2018

(Varga Máté felvétele) 
